\title{
An Expanding Arabian-Nubian Shield Geochronologic and Isotopic Dataset: Defining Limits and Confirming the Tectonic Setting of a Neoproterozoic Accretionary Orogen
}

\author{
Peter R. Johnson ${ }^{*}$
}

6016 SW Haines Street, Portland, OR 97219, USA

\begin{abstract}
Geologic investigations of the Arabian-Nubian Shield (ANS) are supported by a valuable, expanding dataset of geochronologic ages and isotopic analyses. U-Pb zircon SIMS, TIMS, and evaporation data provide robust temporal control on depositional, volcanic, and intrusive events. $\mathrm{Nd}, \mathrm{Sr}, \mathrm{O}$ and, increasingly, $\mathrm{Hf}$ isotopic studies provide insights into magma sources and constraints on crustal recycling. Apart from well-established exceptions where Paleoproterozoic and Archean rocks intercalated in the ANS underwent Neoproterozoic reworking, the data elegantly confirm the Neoproterozoic age and juvenile character of the bulk of the ANS. The geochronologic and isotopic data reveal that some ANS sedimentary, volcanic, and igneous rocks contain pre-Neoproterozoic material as xenocrysts and possible glaciogenic clasts, but give no evidence that the ANS is otherwise underlain by any extensive tracts of older crust. Together with structural mapping, the expanding dataset confirms ANS boundaries where long-inferred in the west and suggests the placement of hitherto uncertain boundaries elsewhere. The suggested boundaries imply that the ANS is of a somewhat smaller size than considered in published discussions, which in turn impacts assessment of Neoproterozoic crustal growth rate. The Arabian-Nubian Shield (ANS) is an accretionary orogen at the northern end (present-day coordinates) of the East African Orogen. It is one of the largest expanses of mantle-derived, juvenile Neoproterozoic crust on Earth, underlying an area of $\sim 2.7 \times 10^{6} \mathrm{~km}^{2}$. Its western boundary is a contact with pre-Neoproterozoic crust belonging to the Saharan Metacraton and Congo-Tanzania Craton. Farther south, the ANS is in contact with the Congo-Tanzania Craton and Mozambique Belt. A southeastern ANS margin is recognized as a contact with pre-Neoproterozoic gneiss belonging to a crustal block referred to as Azania. An eastern ANS margin, long a topic of debate, is suspected beneath Phanerozoic cover in central Arabia, and a northwestern margin with late Mesoproterozoic crust is suspected in Sinai.
\end{abstract}

Keywords: Neoproterozoic, juvenile crust, xenocryst, crustal recycling, Nd, O, Hf, U-Pb dating.

\section{INTRODUCTION}

The Arabian-Nubian Shield (ANS) evolved between $\sim 870$ and $550 \mathrm{Ma}$ as one of the largest tracts of juvenile Neoproterozoic crust in the world. It extends over $3500 \mathrm{~km}$ north-south and more than 1500 east-west at its widest (Figs $1,2)$, underlying an area of $\sim 2.7 \times 10^{6} \mathrm{~km}^{2}$ in the northern half of the East African Orogen (EAO) [1]. The shield is differentiated by the orientations of sutures, shear zones, and fold belts into northern and southern sectors: the southern shield is dominated by northerly trends; the northern sector by a variety of trends $[2,3]$. Cropping out in western Arabia and northeastern and eastern Africa, the ANS is exposed within the jurisdiction of nine nations: Jordan, Israel, Saudi Arabia, Egypt, Yemen, Sudan, Eritrea, Ethiopia, and Kenya. At times, divergent national scientific objectives and geoscience organizations have made systematic geologic study and synthesis of the entire ANS problematic, but the increasing breadth and detail of recent geologic research, developing opportunities for transnational cooperation, and above all a growing geochronologic and isotopic dataset, are leading to new insights and a better understanding of the vast

*Address correspondence to this author at the 6016 SW Haines Street, Portland, OR 97219, USA; Tel: +1 503293 1776;

E-mail: petergeo@earthlink.net array of geologic phenomena presented by the shield. The ANS is a world-class laboratory for the study of Neoproterozoic crustal processes. This special issue of The Open Geology Journal is a tribute to geologic research in the region and celebrates leading thinkers over the past several decades. But continuing progress in the resolution of questions about the origin, age, and development of the ANS is critically dependent on maintaining precise field observations, robust analytic data, and insightful geologic modeling. Geochronologic and isotopic datasets are fundamental tools for the successful execution of this endeavor.

This paper reviews the scope of current geochronologic and isotopic datasets for the ANS, with particular emphasis on the contribution that geochronologic and isotopic data make to our understanding of its margins and the manner in which new data consistently confirm earlier conclusions about its juvenile character. The review concentrates on geochronologic and isotopic results published during the past 10 years; discusses the growing consensus that the ANS is, indeed, juvenile crust, and describes the important impact of these datasets on current geoscience community understanding of the ANS boundaries. 


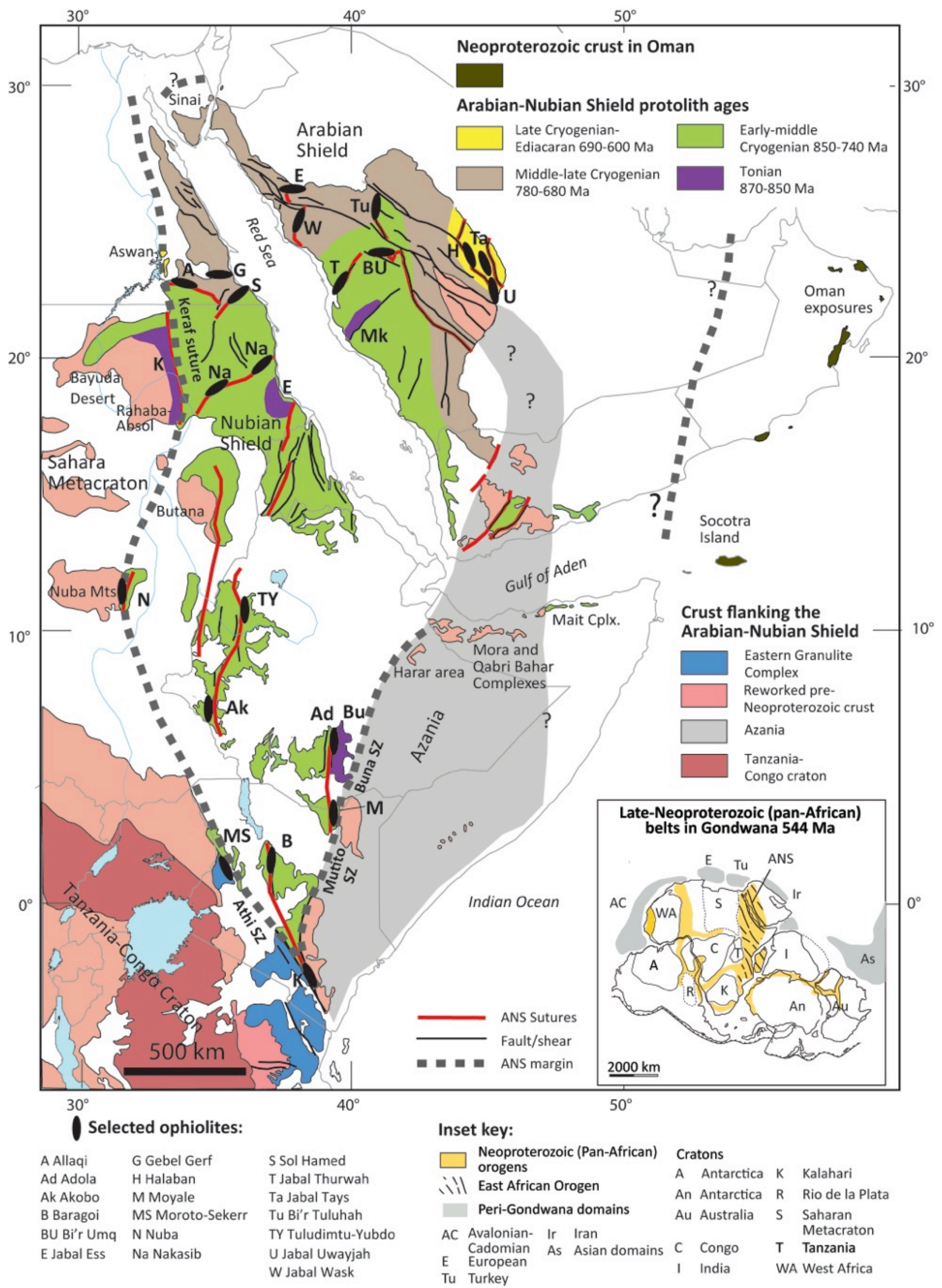

Fig. (1). The Arabian-Nubian Shield in relation to older crust on its margins (after [3]). Ophiolites schematically shown after [4]: A Allaqi; Ad Adola; Ak Akobo; B Baragoi; BU Bi'r Umq; E Jabal Ess; G Gebel Gerf; H Halaban; K Kinyiki; M Moyale; MS Moroto-Sekerr; N Nuba; Na Nakasib; S Sol Hamed; T Jabal Thurwah; Ta Jabal Tays; Tu Bi’r Tuluhah; TY Tuludimtu-Yubdo; U Jabal Uwayjah; W Jabal Wask. 


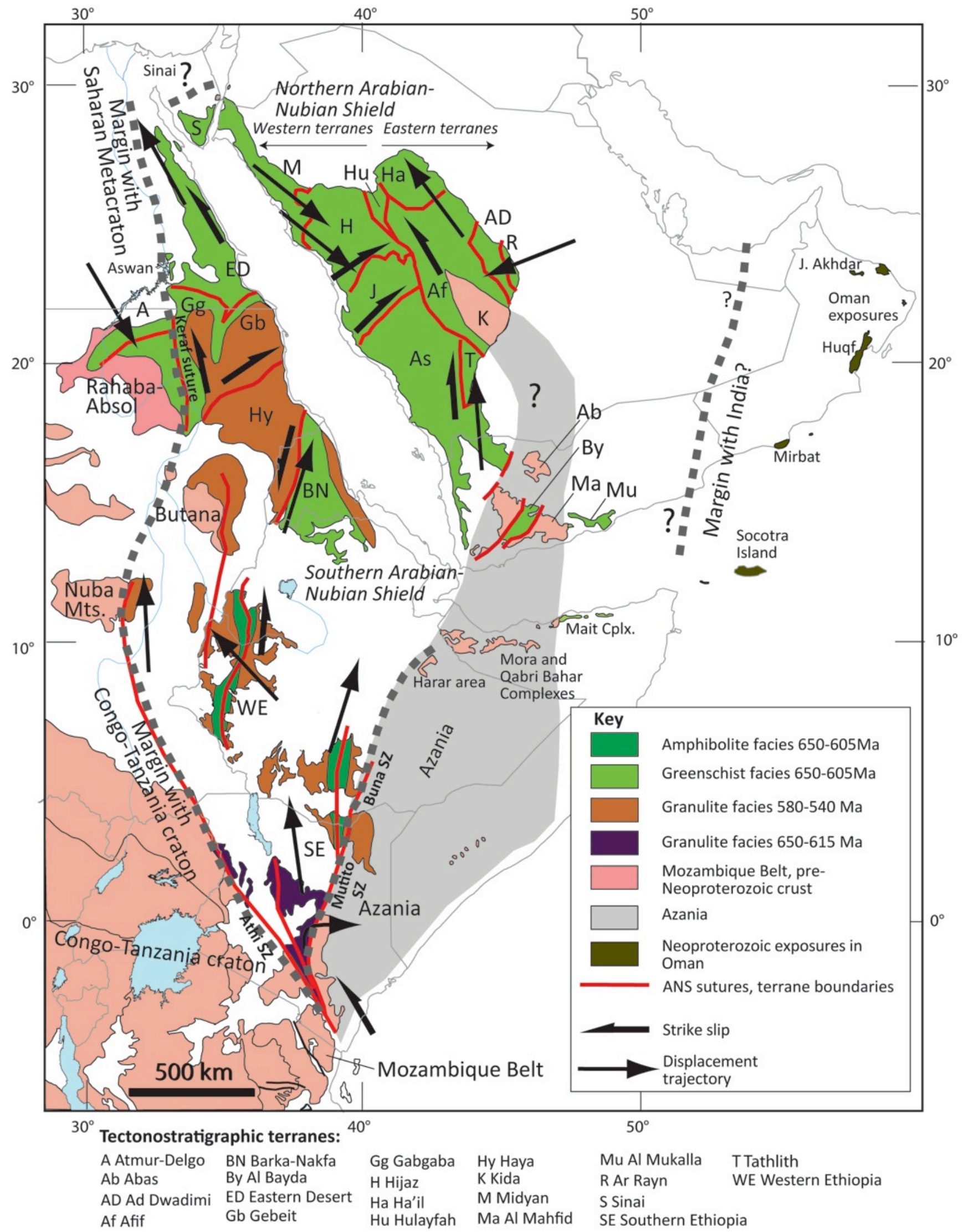

Fig. (2). Structural and metamorphic map of the Arabian-Nubian Shield (after [3]) showing tectonotratigraphic terranes, suture zones, the boundary between eastern and western arc terranes in the Arabian Shield (after [5]), and boundaries between the ANS and flanking older crustal blocks. Arrows show displacement trajectories and sense-of-shear during transpressive orogenic phases in the region. 


\section{SCOPE OF GEOLOGIC RESEARCH IN THE ARABIAN-NUBIAN SHIELD}

The ANS and its surroundings has been the object of geologic investigations for a wide range of economic and scientific reasons. For thousands of years, the rocks of the ANS were explored for gold, silver, copper, and lead, success being marked by hundreds of ancient mines and oretreatment sites that testify to skillful mining and metallurgical innovation as much as 6000 years ago [6]. "Modern" geologic investigations date from the early $19^{\text {th }}$ century. A description of Cretaceous fossils at Giza, Cairo was published well before the middle of the $19^{\text {th }}$ century [7]. A geologic map of northeastern Egypt and Sinai appeared 30 years later [8] showing the approximate outline of what are now known to be Neoproterozoic porphyritic granite, granite, and sandstone, and flanking Phanerozoic limestone and sandstone (Fig. 3). Ten years later, a geologic map was published [9] covering part of present-day Saudi Arabia showing areas of granite and "trap" or metamorphosed volcanic rocks now assigned to the Arabian Shield, areas of sandstone now assigned to the Lower Paleozoic cover unconformable on the shield, and areas of volcanic rock now assigned to Cenozoic flood basalt that make up the "harrat" of western Arabia. Descriptions and reports on geologic features in Palestine, Jordan, and northern Arabia began to regularly appear from 1848 onward (e.g., [10-12]); geologic reports of Kenya started appearing in 1859; the Egyptian Geological Survey was established in 1896; geologic mapping in Sudan began in 1905. Pioneering studies of regional geology were published in the early to mid- $20^{\text {th }}$ Century [13-16] and important syntheses of work on the rocks of the Arabian-Nubian Shield have been published since (e.g. [17-21]). Ground-breaking maps and reports on the geology of the Arabian Peninsula came out of joint work by ARAMCO and the U.S Geological Survey culminating in publication of the 1:2,000,000-scale "Geologic Map of the Arabian Peninsula" [22]. Major reviews of the geology of the region in the past two decades introduced the term "East African Orogen" [1]; emphasized the juvenile character of the ANS [23]; and described the "Saharan Metacraton" on the western margin of the ANS [24]. Other reviews summarized information about the accretionary and deformational history of the ANS [25], and placed the ANS in the broader context of eastern Gondwana amalgamation, at the same time introducing the concept of a block of preNeoproterozoic crust, "Azania", extending into east-central and southern ANS from Madagascar and Somalia [26]. More recent papers describe the isotopic variability of the ANS in Saudi Arabia and crustal structure of the Arabian Plate [5, 27], and synthesize the late Cryogenian-Ediacaran history of the ANS, and accretionary tectonics in the East African Orogen $[2,3]$. A highly significant on-line review of the Saudi Arabian ANS is [28] and a text on the geology of the Saudi Arabian Shield has recently been published by the Saudi Geological Survey [30].

There are many reasons for scientific exploration and study of the Arabian-Nubian Shield. Foremost is that the shield comprises one of the largest expanses on Earth of well-exposed juvenile Neoproterozoic rocks, making the region a unique locale for the study of Neoproterozoic earth- forming processes. The rocks are less deformed and metamorphosed than exposures of Neoproterozoic age elsewhere, and their primary depositional, intrusive, mineralogical, and chemical characteristics are well preserved. Soil and vegetation cover is minimal, rock samples are readily available for study, and the prevailing desert climate means that samples are relatively little altered although they are sometimes remarkably friable. Fundamentally, the ANS provides one of the most accessible natural laboratories on Earth for investigating Neoproterozoic geology and for studying some of the most profound environmental, geochemical, and biological changes ever found in Earth history. Such changes, between 1000 and $540 \mathrm{Ma}$, include: (1) rapid evolution of eukaryotes and the appearance of metazoa; (2) major episodes of continental glaciation that may have extended to low latitudes; (3) marked increases in the oxygen concentration of the atmosphere and hydrosphere; (4) the reappearance of sedimentary banded-iron formations; (5) striking temporal variations in the isotopic composition of $\mathrm{C}$ and $\mathrm{Sr}$; (6) the unambiguous establishment of plate-tectonic processes; and (7) the break-up and reassembly of two of Earth's major supercontinents, Rodinia and Gondwana. Current geologic modeling of the ANS is essentially underpinned by a growing body of geochronologic and isotopic studies. As described here, the results are fundamental to our better understanding of the age, tectonic setting, and development of the ANS Neoproterozoic crust. In many instances, they confirm earlier interpretations; but the new data also reveal unexpected geologic relationships, outline unsuspected crustal units, challenge existing tectonic models, and direct research forward to resolve new questions and issues.

\section{TECTONIC MODEL}

Current investigations in the ANS are based on geologic mapping and structural interpretations supported by a large dataset of $\mathrm{U}-\mathrm{Pb}$ and $\mathrm{Rb}-\mathrm{Sr}$ ages, a smaller number of $\mathrm{Sm}-\mathrm{Nd}$ and ${ }^{40} \mathrm{Ar}{ }^{39} \mathrm{Ar}$ ages, and $\mathrm{Nd}, \mathrm{O}$, and $\mathrm{Hf}$ isotopic data. $\mathrm{U}-\mathrm{Pb}$ dating programs in the shield mostly utilize Secondary Ion Mass Spectrometry (SIMS), Thermal Ionization Mass Spectrometry (TIMS), and Laser Ablation Inductively Coupled Plasma Mass Spectrometry (LA-ICP-MS) analyses of single zircons. Some programs use $\mathrm{Pb} / \mathrm{Pb}$ evaporation techniques on zircon or $\mathrm{U}-\mathrm{Pb}$ spot methods on titanite.

The ANS is modeled as a collage of oceanic island arcs that evolved during the Neoproterozoic above a multiplicity of subduction zones in the Mozambique Ocean. Recent reviews of the orogenic history of the shield $[2,3]$ provide comprehensive information about the depositional, deformation, and tectonic evolution of the region. The Mozambique Ocean was a large basin on the margin of supercontinent Rodinia located between the crustal blocks of India, the Saharan Metacraton, and the Congo-Tanzanian Craton. ANS arc formation occurred over a $\sim 300$-million year period encompassing supercontinent Rodinia break-up and the assembly of supercontinent Gondwana. The arcs have tholeiitic to calc-alkaline, and locally MORB chemistry and include basalt, boninite, andesite and rhyolite, voluminous volcaniclastic and sedimentary rocks, and large 


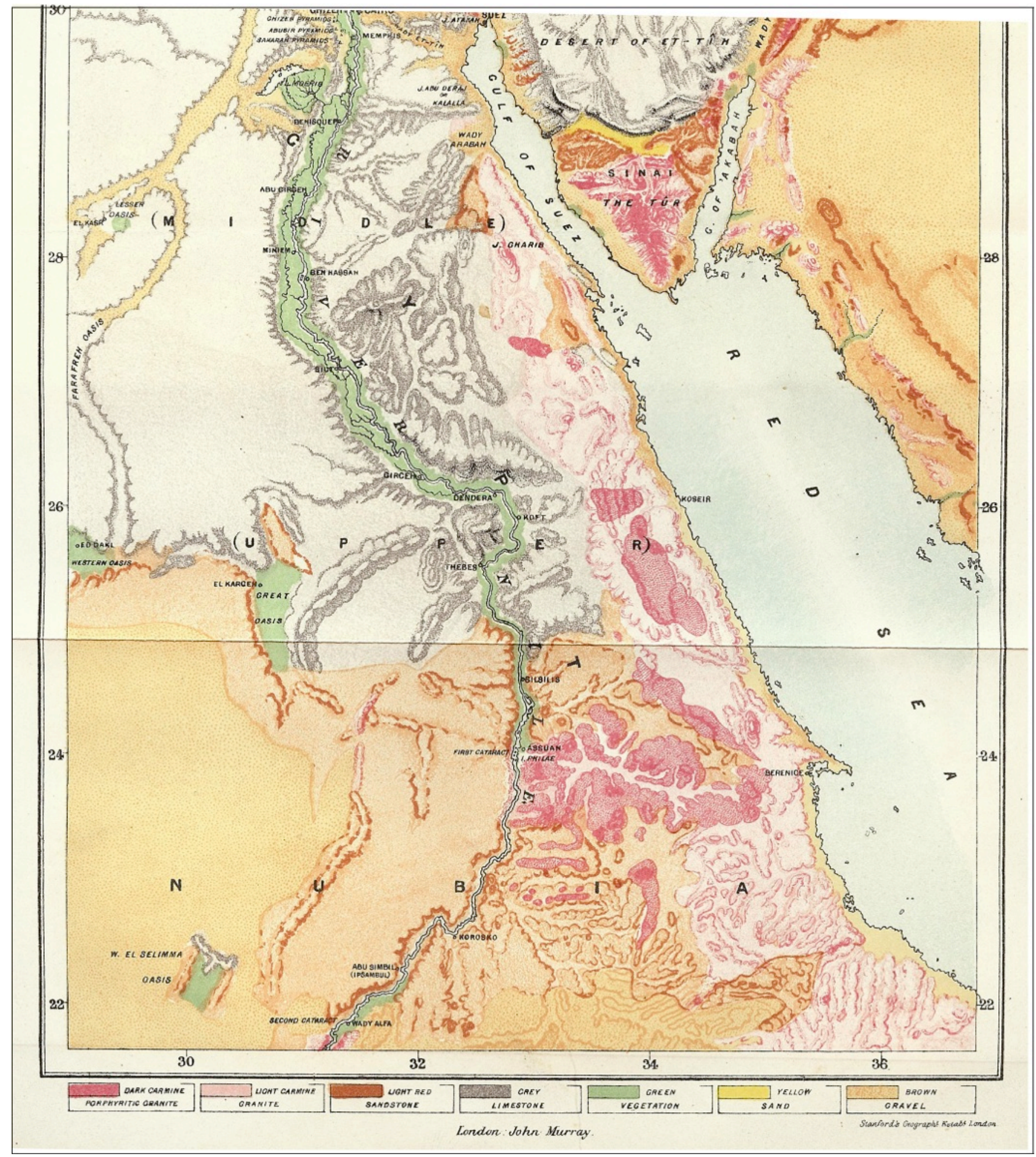

Fig. (3). Part of a $19^{\text {th }}$ century map of northeastern Egypt and Sinai [8]-an example of early geologic investigations in the ANS-showing areas of porphyritic granite, granite, and sandstone now assigned to the Nubian Shield, flanked by limestone and sandstone, now assigned to the Phanerozoic.

amounts of TTG suites comprising diorite, tonalite, trondhjemite. and granodiorite. Oceanic crust in the shield, represented by ophiolite complexes, ranges from 845 to 675 Ma (Fig. 4); arc assemblages range from $\sim 870$ to $615 \mathrm{Ma}$. Based on differences in age of formation, stratigraphy, structural style and, locally, isotopic characteristics, the arc assemblages are divided into tectonostratigraphic terranes (Fig. 2). Boundaries between the terranes are ophiolitedecorated shear zones or sutures and transcurrent shear zones. The oldest arc rocks in any given terrane are referred 


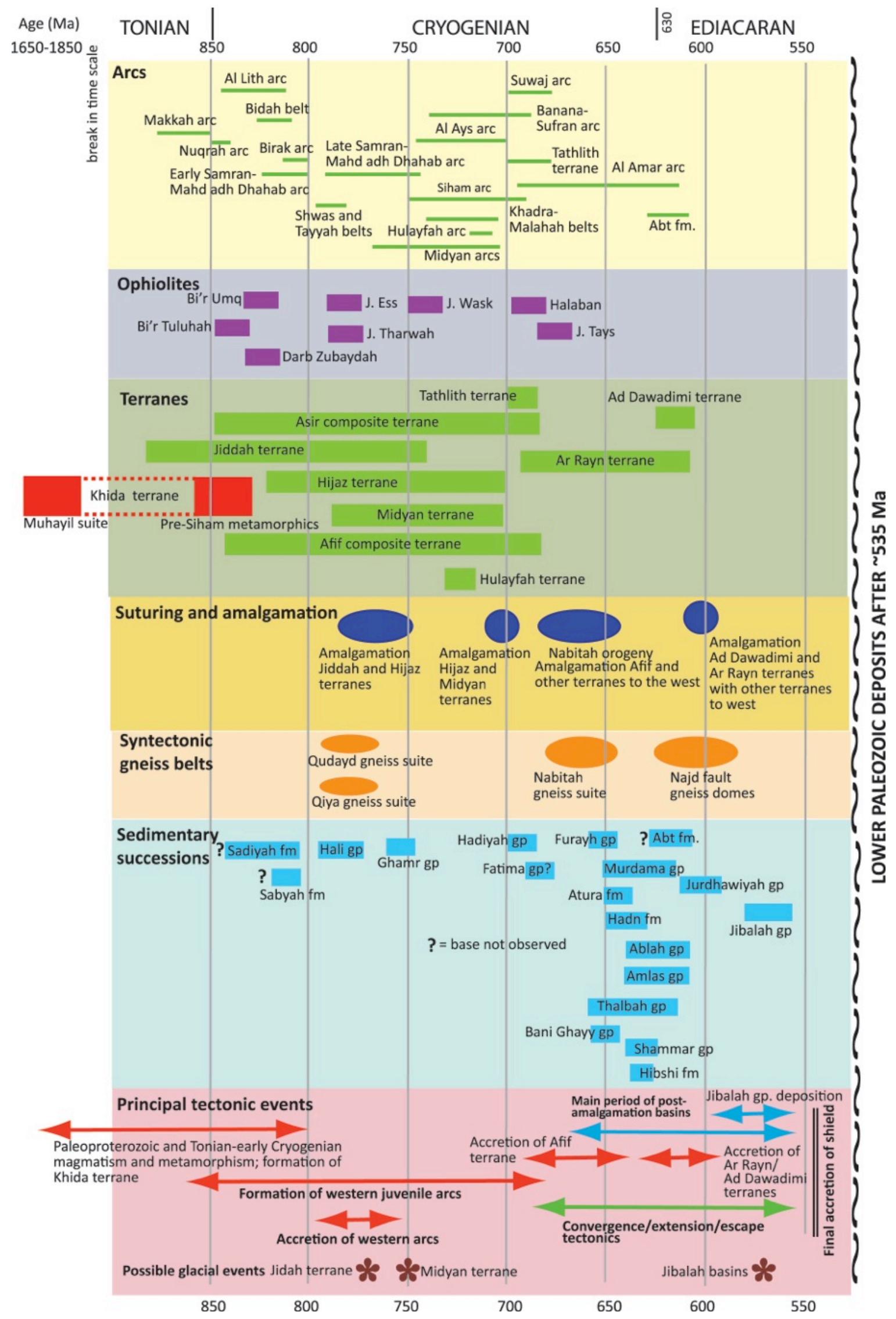

Fig. (4). Depositional, volcanic, intrusive, and orogenic events in the Arabian Shield: an example of a regional timeframe that would not be possible without comprehensive $\mathrm{U}-\mathrm{Pb}, \mathrm{Rb}-\mathrm{Sr}$, ad $\mathrm{Sm}-\mathrm{Nd}$ dating. After [29]. 
to as terrane protoliths (Fig. 1). Most protoliths are early to middle Cryogenian (Fig. 1), but Tonian rocks are locally preserved in the central and southern ANS, middle to late Cryogenian rocks are found in the north, and late Cryogenian-Ediacaran units crop out in the far east and west. Arc amalgamation and suturing occurred between $\sim 780$ and $600 \mathrm{Ma}$, and accretion between the ANS and the Saharan Metacraton, reflecting terminal collision of the ANS and western Gondwana blocks, occurred $\sim 650-580 \mathrm{Ma}$. The ANS is at the northern end of the East African Orogen (Fig. 1; inset), a belt of deformed and metamorphosed rocks that extends through Arabia and Northeast Africa into East Africa and Antarctica. The belt is one of many late Neoproterozoic orogenic belts that wrap around and lie between older cratonic blocks mostly inherited from Rodinia (Fig. 1; inset). Such belts came into being as a result of phases of orogeny between $\sim 850$ and $550 \mathrm{Ma}$, culminating in the assembly of Gondwana. Metamorphic grades in the ANS range from granulite facies in the south to greenschist facies over much of the north and developed during periods of transpressional east-west shortening, north-south extension, strike-slip shearing, and tectonic escape (Figs. 2, 4).

\section{GEOCHRONOLOGIC AND ISOTOPIC DATABASE}

\section{U-Pb Zircon Dating in the ANS}

Geochronology, based on the decay of radioactive elements, has been done in the ANS since the 1950s. Age determinations at first used the K-Ar method, quickly followed by the $\mathrm{Rb}-\mathrm{Sr}$ method. U-Pb age determinations became common after the late 1970s [30], initially based on the conventional method of analyzing multigrain zircon populations but more recently using techniques that analyze individual spots in individual zircon grains. Spot U-Pb analyses coupled with cathodoluminescent examination or back-scattered imaging of grain interiors have fundamentally improved the reliability and interpretation of zircon age determinations, providing a meaningful chronology of geologic events and a means of comparing and contrasting geologic histories in different parts of the shield. Current U$\mathrm{Pb}$ analyses of single zircons in the ANS are being done by Secondary Ion Mass Spectrometry (SIMS), Thermal Ionization Mass Spectrometry (TIMS), Laser Ablation Inductively Coupled Plasma Mass Spectrometry (LA-ICPMS), and evaporation techniques. A comprehensive catalogue of $\mathrm{U}-\mathrm{Pb}$ and $\mathrm{Pb}-\mathrm{Pb}$ zircon crystallization ages of 559 igneous rocks is given in Appendix $\mathrm{A}$ in [31]. Catalogues for ages in the Arabian Shield are given in [28] and [32].

The current geochronologic database for the ANS contains U-Pb ages for several hundred rock samples. Fig. (5) illustrates the geographic spread of locations where volcanic and plutonic rock samples have been dated by $\mathrm{U}-\mathrm{Pb}$ multi-grain and single-grain zircon methods and shows the spread of volcanic and plutonic formation ages. The available dataset is reasonably comprehensive and helps to constrain the ages of most depositional, intrusive, and deformational events in the shield (Fig. 4). Overall, as shown by Fig. (1), Tonian and early Cryogenian igneous rocks (volcanic and intrusive) are concentrated in the Jiddah terrane (in the Arabian Shield), the Gebeit and Barka-Nakfa terranes (in the Nubian Shield), and Western Ethiopia, and late Cryogenian and Ediacaran igneous rocks are common in the northern and eastern ANS (see Fig. (2) for terrane locations).

The geochronologic dataset must be approached with caution because there are significant geographic gaps, there has been a sampling bias in many of the dating campaigns, and detailed chronologies for many critical events in the shield are lacking. Thus, rocks in several parts of the shield, such as the southern Gabgaba and Haya terranes and the Butana area, in the Nubian Shield, and northern Hijaz terrane in the Arabian Shield, have not been systematically dated. Even in areas already dated, the available results are for dating campaigns that preferentially sampled granitic rocks at the expense of mafic intrusions and volcanic rocks because of the ease of finding zircons. Within the granite family, moreover, many age results derive from late- to posttectonic plutons at the expense of less well-exposed or more altered pre- and syn-tectonic intrusions. As a consequence, the ages of many arc assemblages in the shield are not well established, and there is a dearth of robust information about the ages of collisional and metamorphic events.

$\mathrm{Be}$ that as it may, however, the present $\mathrm{U}-\mathrm{Pb}$ dataset for the ANS is a rich source of geologic information. It provides a working control on tectonic modeling and is the basis for a number of important time-space reviews of geologic events in the shield. Perhaps the most important conclusion over the past decade is the demonstration that, although pre-Neoproterozoic crust crops out in the Khida terrane in Saudi Arabia and the Abas and Al Mahfid terranes in Yemen (Fig. 2), there is no significant extent, if any, of pre-Neoproterozoic crust beneath the shield. Critical reviews of geochronological and isotopic data from both the northern ANS (Saudi Arabia, Egypt, Sudan: $[2,5,23,31,41-50])$ and the southern ANS (Eritrea, Ethiopia, Kenya: [40, 51-54]) show that the internal portions of the ANS are dominantly composed of juvenile Neoproterozoic crust. Another important conclusion, despite the caveat mentioned above, is the growing ability to assign time ranges to volcanic, magmatic, and deformation events. A recent study in the Eastern Desert [45], for example, combined new dating with earlier results and considerably refined the history of magmatism in the Eastern Desert, identifying 6 pulses of magmatism and/or metamorphism at (1) 705-680 Ma, (2) 660 Ma, (3) 635-630, (4) 610-604, (5) 600-590, and (6) 550-540 Ma. In northern ANS, a new dataset of high-resolution ion-probe dating of post-tectonic granitoid plutons in Sinai has been acquired [38], demonstrating that a commonly accepted model of a transition from calc-alkaline to within-plate alkaline to peralkaline magmatism in the northern ANS at about $610 \mathrm{Ma}$ ([55] is too simplistic. The new data constrain calc-alkaline magmatism at $\sim 635-590 \mathrm{Ma}$ and alkaline magmatism at $\sim 608-580 \mathrm{Ma}$ and show that considerable overlap occurred between the two. During this period, the calc-alkaline suite underwent a transition from mafic to felsic magmatism, but a voluminous pulse of granodiorite to granite intrusion at 610 $600 \mathrm{Ma}$ coincided with the onset of alkaline magmatism. On a larger scale, compilation of age data for the Arabian Shield [29] allows development of the time frame for a wide range 


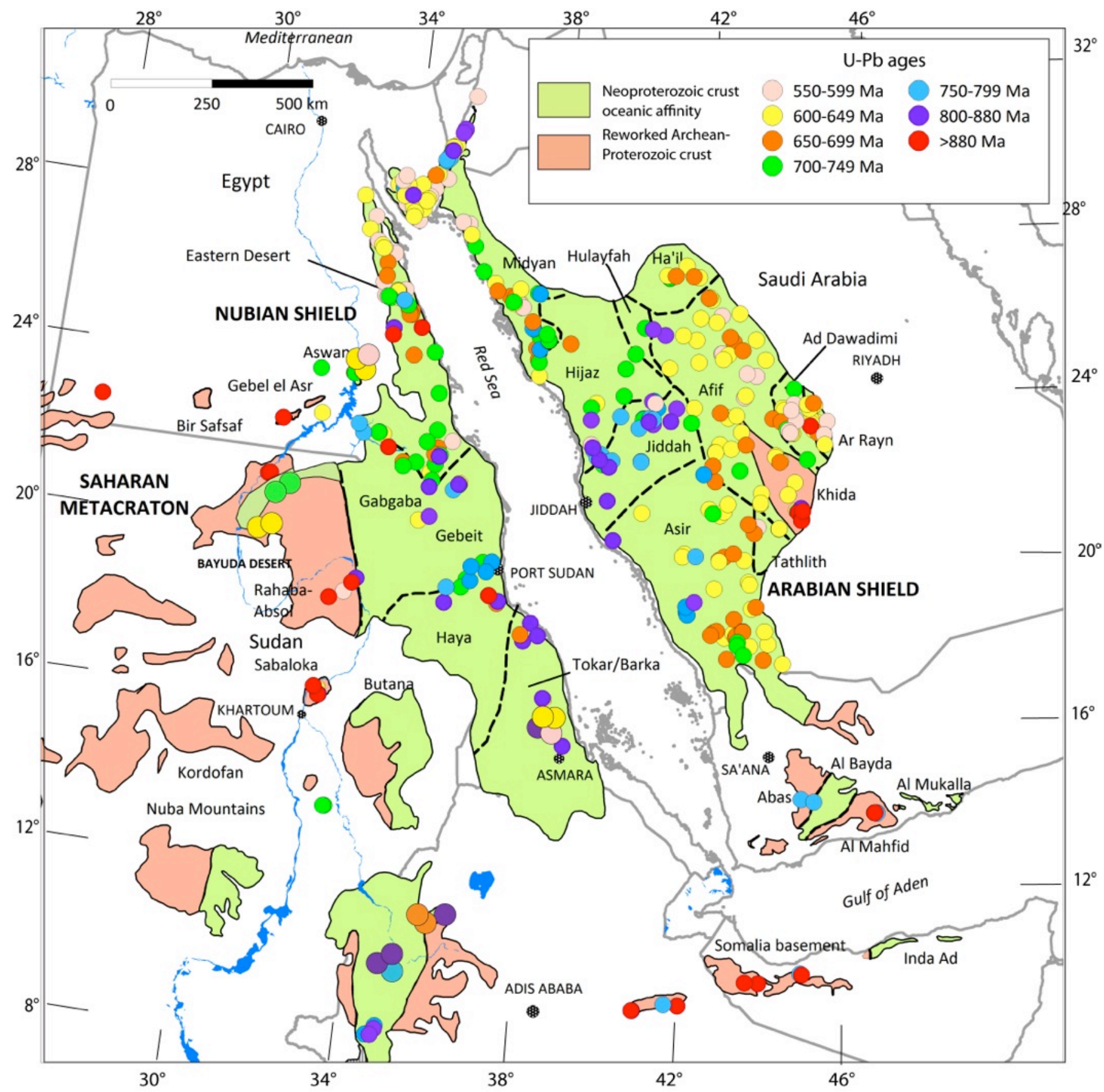

Fig. (5). Geographic spread of locations of plutonic and volcanic rock in the Arabian-Nubian Shield collected for U-Pb single-grain and multi-grain zircon dating, illustrating the range of ages obtained. Sources of data: references cited in [31] with additions from [33-37]. Additional sample locations exist for parts of the Eastern Desert, Sinai, and the Midyan terrane (e.g. [38-45], but are omitted here because of crowding of data points.

of crustal processes illustrated in Fig. (4), in some instances confirming earlier tectonic models, in other cases suggesting refinements.

\section{Inheritance}

One outgrowth of current work on single zircon dating is the realization that inheritance is a significant, if not widespread, phenomenon in the ANS. A first-order definition of the Arabian-Nubian Shield is as a tract of juvenile Neoproterozoic crust in northeast Africa and Arabia
[23], yet numbers of Neoproterozoic rock samples from the shield contain zircons older than the formation ages of the samples. A recent review [31] of $\mathrm{U}-\mathrm{Pb}$ single zircon dating in the ANS, based on whole-grain TIMS techniques (14 rock samples), evaporation techniques (108 samples), point analyses SIMS (182 rock samples), or LA-ICP-MS (3 rock samples), compiled a database of 2393 individual ages (Fig. 6A). As expected, the majority of single-zircon ages are Neoproterozoic, consistent with the Neoproterozoic formation ages of the rock samples, but 23 of the rock samples used for dating contain zircon grains or zircon cores 
older than the formation ages of the host rocks, i.e. are inherited or xenocrystic. For the purpose of this study, xenocrystic grains were defined as those that are $<10$ percent discordant (i.e., provide reliable geochronologic information) yet are 200 million years older than their host rock [31]; other workers treat any zircon older than the statistically determined mean age of a zircon population as xenocrystic, in which case "xenocrystic grains" may be as little as tens of millions of years older than the host rock. In the study by [31], it was found that 100 xenocrystic zircon grains from ANS plutonic rock samples date between $\sim 880 \mathrm{Ma}$ and the Archean (Fig. 6B). Most of the samples are concentrated in the northern ANS, and particularly in the Arabian Shield (Fig. 7), a distribution that is currently unexplained. It has yet to be determined if the distribution is accidental - an effect of xenocrysts not yet being recognized or searched for in current studies - or a geologic reality; and if real, what does it signify? For the present, pre-Neoproterozoic xenocrysts in the ANS are noted as a significant feature of the geology that needs to be further assessed.

Another feature about xenocrysts in the ANS that needs to be assessed is that the majority of the rock samples containing $>880$ Ma xenocrysts have middle Cryogenian formation ages; 16 out of a total of 23 samples are $>700 \mathrm{Ma}$ of which 7, or $\sim 30$ percent, have ages ranging 750-799 Ma, representing middle Cryogenian arcs; the remaining 7 samples are $<700 \mathrm{Ma}$. A further relationship apparent in the current $\mathrm{U}-\mathrm{Pb}$ zircon dataset is that, for whatever reason, volcanic rocks contain 59.2 percent of the $>880 \mathrm{Ma}$ xenocrysts and plutonic rocks only 40.8 percent [31] even though the dataset contains three-times as many analyses of plutonic rocks than volcanic rocks and, among the volcanic units, xenocrysts preferentially occur in mafic rather than felsic rocks.

These temporal and lithologic relationships are particularly well illustrated by data from the Central Eastern Desert of Egypt where an extensive program of zircon $\mathrm{U}-\mathrm{Pb}$ single zircon dating and neodymium and hafnium isotope analyses has been carried out on (1) 750 Ma putative glaciogenic diamictite, mudstone, basaltic and andesitic volcanic rocks, and associated gabbro, diabase, and on (2) Ediacaran post-tectonic granite intrusions [49, 56, 57]. The mudstone contains detrital zircon ranging between 1198 and 2765 Ma. The underlying volcanic rocks and gabbro and diabase intrusions contain as many as 28 Archean, Paleoproterozoic, and Mesoproterozoic xenocrystic zircons. The sedimentary and magmatic rocks clearly received significant input from older crustal sources. At the same
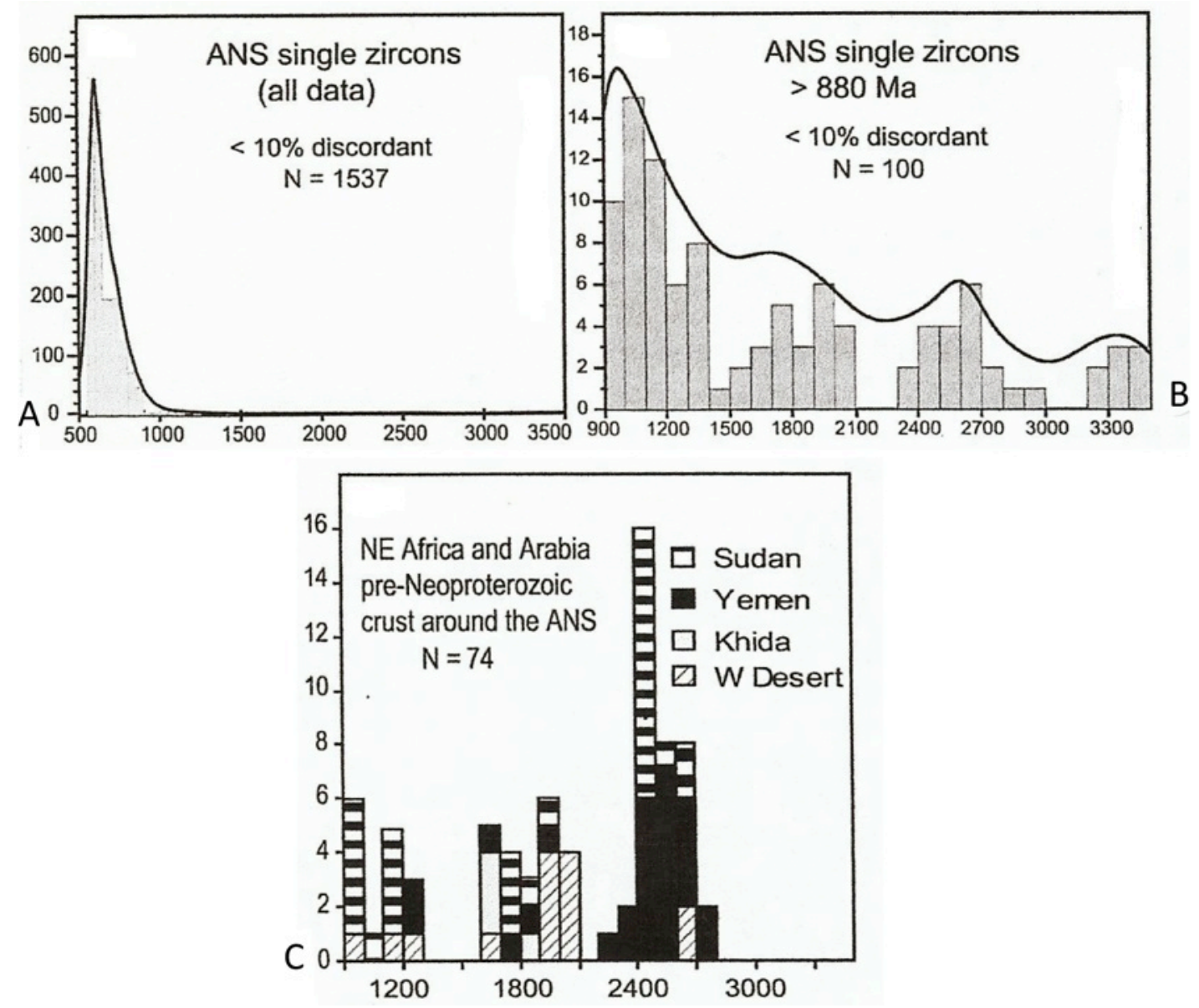

Fig. (6). Distribution of single zircon ages from the ANS and pre-Neoproterozoic crust in the region (after [31]). (A) Density probability curve of all ages $<10 \%$ discordant in the dataset compiled by [31], which see for sources. (b) Histogram and probability curve of ages $>880$ Ma that are $<10 \%$ discordant. Bin size 100 m.y. Most of these ages are obtained from rocks in the ANS that have Neoproterozoic formation ages, and the curve effectively illustrates the age range of xenocrystic zircon in ANS plutonic rocks. (C) Ages of pre-Neoproterozoic crust around the ANS, shown to illustrate possible sources of xenocrystic zircons plotted in $\mathbf{B}$. 
time, the volcanics and associated gabbro and diabase yield positive age-adjusted initial $\varepsilon_{\mathrm{Nd}}(+5.1$ to +8.9$)$ and $\mathrm{Nd}$ model ages of $0.64-0.79 \mathrm{Ga}$, indicating that they represent juvenile crust formed from magma extracted from a depleted mantle source [57]. The Ediacaran (633 $\pm 7 \mathrm{Ma} ; 603 \pm 8 \mathrm{Ma})$ posttectonic granites, on the other hand, contain no preNeoproterozoic xenocrystic zircon; they have consistently positive $\varepsilon \mathrm{Hf}(\mathrm{t})$ values in a relatively restricted range of +4.0 to +11.9 and Hf crustal model ages $\left(\mathrm{Hf}-\mathrm{T}_{\mathrm{Dm}}{ }^{\mathrm{C}}\right)$ of $0.81-1.3$ $\mathrm{Ga}$, and $\varepsilon_{\mathrm{Nd}}(\mathrm{t})$ values of +3.4 to +7.0$)$. The granites yield isotopic values similar to those expected in contemporary depleted mantle, and evidently crystallized from magma that assimilated no older crustal material [49].

As shown in Fig. (6), the single zircon $\mathrm{U}-\mathrm{Pb}$ ages for the ANS are predominantly Neoproterozoic (Fig. 6A). Such a distribution is consistent with the geology of the shield, although it should be noted that the prominent peak at 600$625 \mathrm{Ma}$ skews the distribution so that it is not representative of the ANS as a whole [31] but disproportionately reflects magmatism associated with terminal collision between eastern and western Gondwana blocks at $\sim 650-580 \mathrm{Ma}$. The tail on the age-distribution curve is notable however and, in detail (Fig. 6B), resolves into four peaks: NeoMesoproterozoic (0.95-1.15 Ga), late Paleoproterozoic (1.7$2.1 \mathrm{Ga})$, Paleoproterozoic-Neoarchean (2.4-2.8 Ga); and Paleoarchean $(>3.2 \mathrm{Ga})$. The three younger peaks correspond to the ages of pre-880 Ma crust known within and around the ANS (Fig. 6C). Latest Mesoproterozoic-early Neoproterozoic (Kibaran-age) crust is exposed in the Bayuda Desert and suggested in Sinai by the recent discovery of metasediments containing $\sim 1.0$ Ga zircons [58]. Paleoproterozoic crust crops out in the Khida terrane in the eastern part of the Arabian Shield [59], and in the Saharan Metacraton [24], and Neoarchean rocks are found in Yemen and Sudan [60-62]. The oldest peak of xenocrystic zircons $(>3.2 \mathrm{Ga})$ has no known counterpart around the ANS.

\section{Detrital Zircon Spectra}

A topic complementary to that of inherited zircons in igneous rocks is the analysis of detrital zircons in sedimentary rocks in and around the ANS. Fig. (8) shows probability plots of detrital zircon populations from Ediacaran sandstones and conglomerates in the northern and eastern shield (Elat and Rutig Conglomerates, Abt formation), from Cambro-Ordovician sandstone unconformable on the northern margin of the shield, and for comparison, from Ediacaran-Cambrian sediments in Oman (Huqf Supergroup). Detrital zircons in sedimentary rocks provide a valuable large-scale sample of provenance material. Over most of the age ranges illustrated, the distributions are consistent with the ages in adjacent crystalline rocks, suggesting local derivation from known basement. Over parts of the ranges, however, the detrital ages do not match ages of known basement, and in these cases the detrital spectra are powerful evidence for derivation from distant sources or the hitherto unsuspected nearby presence of older crust.

The Elat Conglomerate is a case in point (Fig. 8A). The Elat Conglomerate consists of immature polymict conglomerates deposited in grabens developed on older exhumed and eroded ANS igneous-metamorphic rocks [63]. Zircon grains are dominantly stubby with subhedral to euhedral shapes; many have fine oscillatory or broad parallel zoning, suggestive of magmatic origins, and the grains were evidently derived by erosion of igneous/crystalline sources. The youngest zircons in the unit constrain its depositional age to $\sim 580 \mathrm{Ma}$. This corresponds to the youngest age of crystalline rocks in the basement. Deposition of the conglomerate age indicates that igneous activity in the northern ANS had ceased by this $580 \mathrm{Ma}$ date, followed by exhumation and erosion providing detrital material for the conglomerate. The $\mathrm{U}-\mathrm{Pb}$ age spectrum of some 175 detrital zircons from the conglomerate defines two peaks at $\sim 615 \mathrm{Ma}$ and $\sim 795 \mathrm{Ma}$, separated by a gap of about 100 million years, as well as a small scatter of ages up to $1.0 \mathrm{Ga}$ [63]. Four grains have older ${ }^{207} \mathrm{~Pb} /{ }^{206} \mathrm{~Pb}$ ages of $1.97,2.07,2.12$, and 2.5 $\mathrm{Ga}$, and a few grains have ages between 900 and $1100 \mathrm{Ma}$. In the cases of the $\sim 795 \mathrm{Ma}$ and $\sim 615 \mathrm{Ma}$ peaks, the detrital zircons are reasonably interpreted as derived from the northern ANS basement, which contains 880-760 Ma early island-arc rocks and 660-580 Ma granitoids and volcanics. The source of the Paleoproterozoic grains is currently unknown. The 900-1100 Ma ages suggest derivation from a late Kibaran-age or early Tonian crust, compatible with the older crust mentioned above, inferred on the basis of recently obtained geochronologic and isotopic data $[39,58]$.

The Rutig Conglomerate in central Sinai is a similar Ediacaran deposit (620-590 Ma) (Fig. 8A) [64], interbedded with volcanic rocks, sandstone, and siltstone, and unconformably overlying gneiss and metasedimentary rock. The age probability pattern of SIMS $\mathrm{U}-\mathrm{Pb}$ ages for zircons separated from two conglomerate samples shown in Fig. $(\mathbf{8 A})$ reveals a similar distribution to the Elat Conglomerate, with a major contribution from a 600-860 Ma source, a prominent gap at $640-710 \mathrm{Ma}$, and some contribution from 900 to $1100 \mathrm{Ma}$ components. The implied provenance ages are, like those for the Elat conglomerate, mostly compatible with the known ANS basement, but also suggest that pre-870 Ma sources of dominantly latest Mesoproterozoic to earliest Neoproterozoic components are more widespread in the northernmost ANS than previously appreciated.

The Abt formation, in the eastern ANS, is a monotonous thick succession of muscovite-biotite-chlorite-quartzfeldspar schist derived from Ediacaran sandstone or wacke protoliths. The formation possibly represents a forearc basin associated with a late Cryogenian-Ediacaran volcanic arc in the eastern Arabian Shield [65]. The detrital dataset (Fig. 8B) comprises 391 ages, of which 46 are 95-105 percent concordant and geologically meaningful. Neoproterozoic ages dominate the record (Fig. 8B), but a MesoproterozoicPaleoproterozoic tail has small peaks at $\sim 1.85 \mathrm{Ga}, \sim 2.07 \mathrm{Ga}$, and $2.0 \mathrm{Ga}$. The Neoproterozoic grains are consistent with erosion of adjacent arc rocks of the ANS; Mesoproterozoic and Paleoproterozoic grains could be derived from the Khida terrane to the south or even continental terranes farther south in Yemen, but their exact source remains to be established [65].

The probability curve for detrital zircons from the Huqf Supergroup ( 725-540 Ma) (Fig. 8C) shows a large peak at $\sim 850 \mathrm{Ma}$, smaller Neoproterozoic peaks at $\sim 780 \mathrm{Ma}, \sim 720$ 


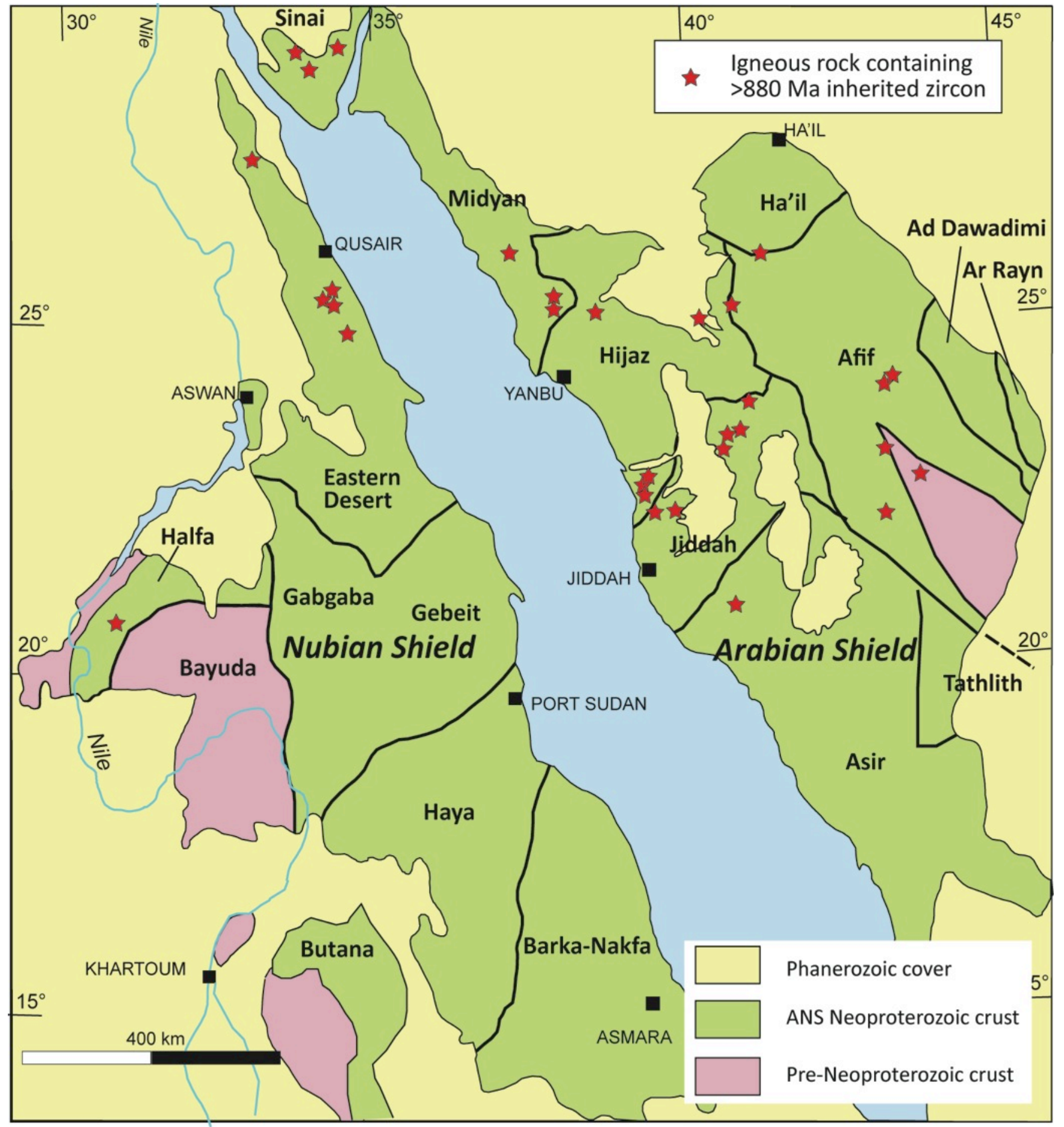

Fig. (7). Simplified map showing the locations of plutonic and volcanic rock samples from the ANS that contain xenocrystic zircons $>880$ Ma. Some locations include more than one sample, but these are not separately shown at the scale of this map. As commented in the text, the apparent absence of xenocrystic zircons in the southern part of the shield needs to be confirmed and, if confirmed, needs to be explained.

$\mathrm{Ma}$, and $\sim 630 \mathrm{Ma}$, and small Paleoproterozoic peaks at $\sim 1.7-\sim 1.95 \mathrm{Ga}$, and $\sim 2.3 \mathrm{Ga}$ (references in [27]). The dominant source region for the Huqf sediment was clearly Neoproterozoic, mainly Tonian to early Cryogenian, consistent with the age of the known basement in Oman [66], but the location of the Paleoproterozoic sources is unknown. The Cambro-Ordovician sandstone curve (Fig. 8C) plots ages of detrital zircons from samples collected in southern Israel and Jordan, part of the vast lower Paleozoic siliciclastic blanket that unconformably overlies the ANS and equivalent crystalline rocks around much of former Gondwana $[67,68]$. The sandstone was deposited by a large fluvial-shallow marine system that developed by $\sim 530 \mathrm{Ma}$ on the newly accreted ANS. Current-direction information [69] suggests that the clastic material in the sandstone was derived from the south, possibly from a region of upland 


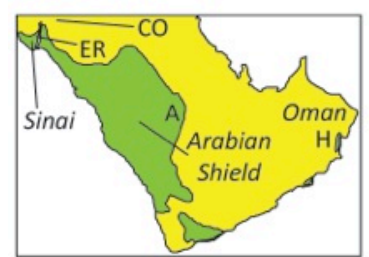

CO - Cambro-Ordovician sandstone ER - Elat and Rutig Conglomerates

A - Abt formation

H- Huqf Supergroup
Elat Conglomerate and Rutig Conglomerate

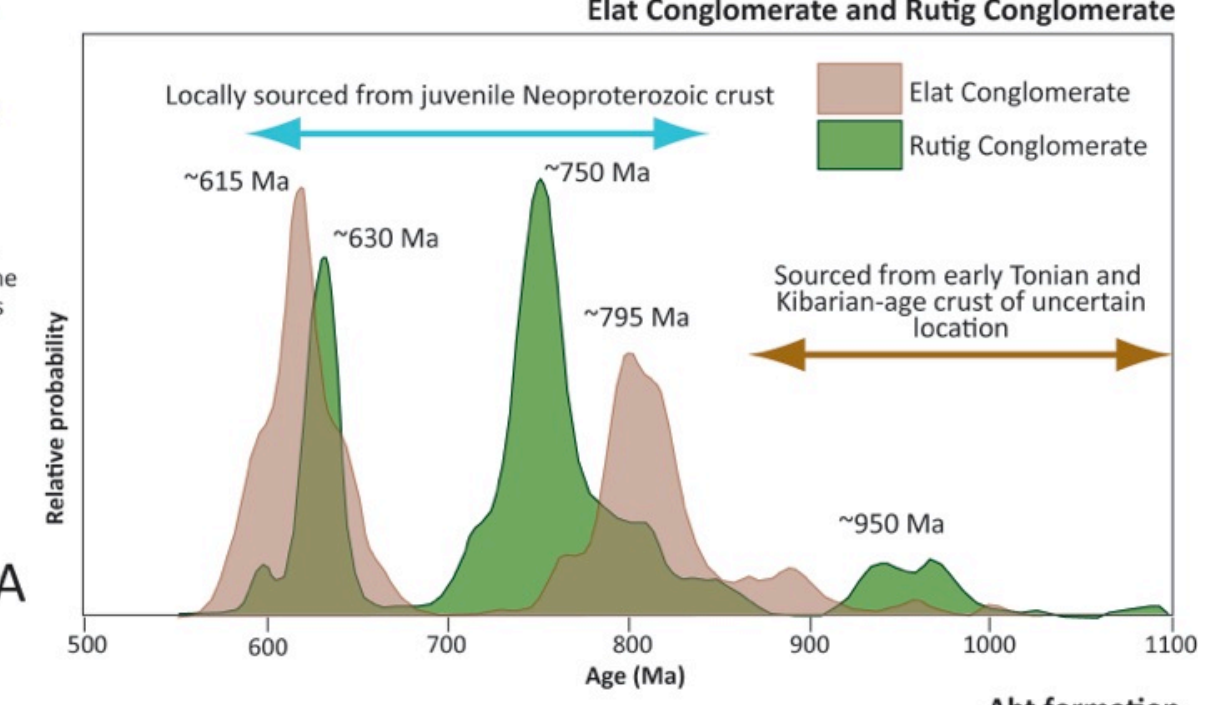

Abt formation

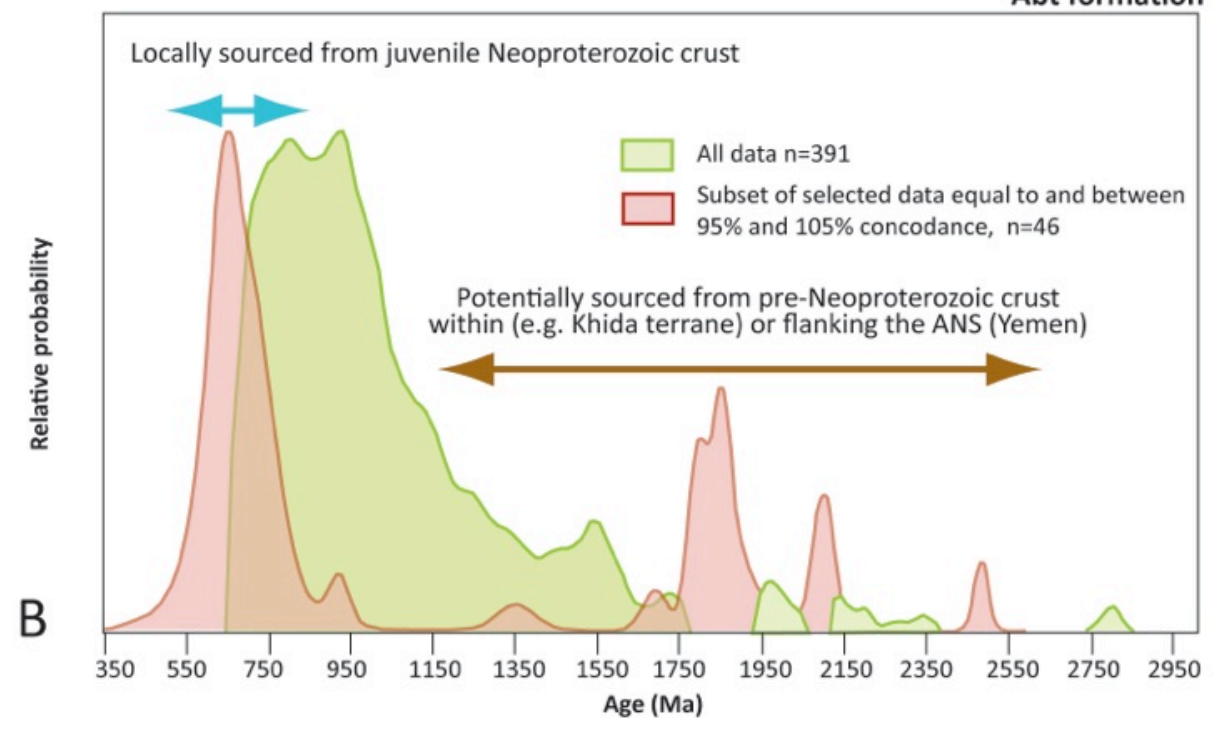

Huqf Supergroup and Cambro-Ordovician sandstone

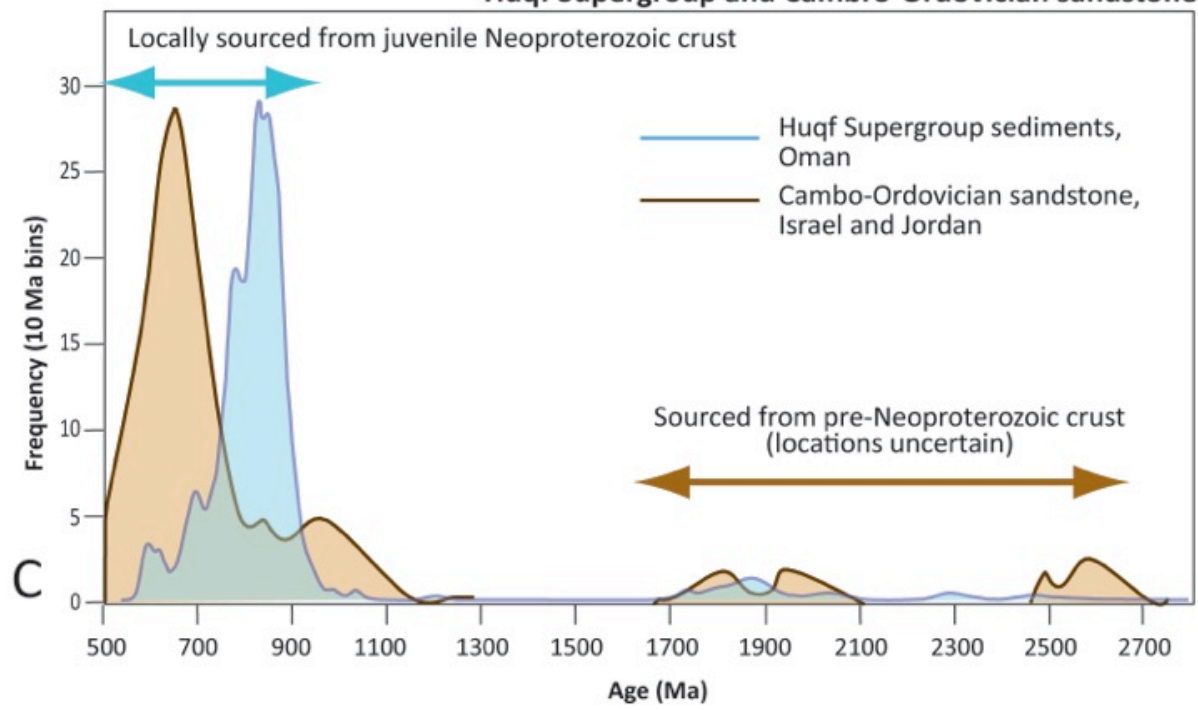

Fig. (8). Age spectra of detrital zircon grains illustrating the age ranges and concentrations of clastic material in Ediacaran sandstone and conglomerate in the ANS and lower Paleozoic sandstone overlying the shield. (A) Data from the Elat and Rutig Conglomerates in the northern ANS (Sinai); after [63] [64] (B) Data from the Abt formation in the eastern ANS after [65]; (C) Data from the Huqf Group, Oman and Lower Cambrian sandstone at the northern edge of the ANS crystalline basement in southern Sinai (references in [27]). 
referred to as the Transgondwanan Supermountain [70]. Similar to the other detrital age records illustrated here, Neoproterozoic ages predominate in the age spectrum, indicating that the detrital sources were chiefly rocks typical of the ANS, but small additional clusters are at $0.9-1.1 \mathrm{Ga}$, 1.65-1.85 Ga, and 2.45-2.7 Ga. The Paleoproterozoic and Archean grains were possibly sourced from the Saharan Metacraton or crust similar to the Khida terrane [67]. Late Mesoproterozoic-early Neoproterozoic crust is known in the Bayuda Desert [71, 72] and, as mentioned, suspected in Sinai $[58,73]$.

It should be noted that the number of detrital zircon studies in the ANS is limited and confined mostly to Ediacaran deposits. Older sedimentary basins in the ANS are widespread [74] and would provide additional suitable material for detrital zircon analysis. Implementation of detrital zircon dating programs is strongly recommended because the acquisition of detrital zircon data can be achieved relatively speedily, and the results would provide crucial insights into the composition and origin of the ANS and of continental crust surrounding the shield. In this regard, a recent study of the ages of detrital zircon grains and clasts in middle Cryogenian ( $\sim 750 \mathrm{Ma})$ Atud diamictite of inferred glacial origin in the Eastern Desert illustrates the value of examining older sedimentary material in the ANS [56]. The diamictite contains clasts of granite, quartz porphyry, arkose, quartzite and other rock types. Of the clasts, one has a formation age of $\sim 750 \mathrm{Ma}$ and presumably represents material eroded from nearby plutons; one is interpreted to have been derived from a Paleoproterozoic source; and another clast contains concordant zircon grains between 1.9-2.9 Ga and may represent a pluton as old as 3.0 $\mathrm{Ga}$. A quartzite clast from the diamictite contains $2.1-2.7 \mathrm{Ga}$ zircons and is believed to be a fragment of rock derived from a Paleoproterozoic-Archean source and an arkose clast, interpreted as a fragment of Neoproterozoic arkose, has zircon grains as old as $2.56 \mathrm{Ga}$, indicating that the arkosic detrital material was derived from Archean crust. The matrix of the diamictite itself contains abundant zircon grains eroded from Neoproterozoic, Paleoproterozoic, and Neoarchean sources.

\section{Isotope Database and ANS History}

Analysis of radiogenic and stable isotopes is a routine step in modern investigations of Earth history, being used to determine the ages of rocks and as tracers to understand geological and environmental processes. To date, one of the most widely adopted approaches is to utilize the radiogenic decay of ${ }^{147} \mathrm{Sm}$ to ${ }^{143} \mathrm{Nd}$ because of the ability of the Sm-Nd systematics to preserve information of geologic significance, minimizing the effects of erosion, sedimentation, high-grade metamorphism, and even crustal melting events that may reset other isotopic systems. Since publication of one of the first $\mathrm{Nd}$ studies in the ANS [75], Nd whole-rock isotope analyses in conjunction with $\mathrm{U}-\mathrm{Pb}$ single zircon dating have become routine in assessments of the ANS (e.g., [72]) and other orogenic belts (e.g., [76]). Other important approaches applied to the ANS since the 1980s are to use lead and strontium isotopes in whole-rock samples [77-79]. More recently, oxygen and hafnium isotopes have become increasingly used.
An important review of $\mathrm{Nd}, \mathrm{Pb}, \mathrm{Sr}$, and $\mathrm{O}$ isotopes in the Arabian Shield is given by [5], and the Nd isotopic character of the western Arabian Shield is discussed by [80]. On a larger scale, [81] compiled $\mathrm{Pb}$ isotope data for the northern part of the EAO and [23] presented a review of $\mathrm{Nd}$ data for the same region. [73] is an important example of the use of $\delta^{18} \mathrm{O}$ values to track the process of supracrustal recycling in the formation of 1.0-1.1 Ga crust in northern Sinai. [63] uses negative $\varepsilon_{\mathrm{Hf}(\mathrm{t})}$ values together with U-Pb dating of single detrital zircon grains to suggest that arc magmas in the same area were contaminated by older crustal components [63]. [49] provides a compelling hafnium isotope study of metasedimentary, metavolcanic, and granitic rocks in the Central Eastern Desert, giving insight into crustal growth in the region.

Two measures are critical in Nd isotope studies: (1) the departure of the initial ${ }^{143} \mathrm{Nd} /{ }^{144} \mathrm{Nd}$ ratio from the chondritic meteorite evolution line, generally expressed using the notation of $\left[\varepsilon_{\mathrm{Nd}}(t)\right]$ where $t$ is the accepted crystallization age of the sample, and (2) the model age $\left(T_{\mathrm{Dm}}\right)$ [82]. The initial ratio gives information about the source of igneous melts, especially with reference to the mantle. Partitioning of Sm and $\mathrm{Nd}$ during fractionation in the mantle to produce felsic melts changes the $\mathrm{Sm} / \mathrm{Nd}$ ratio of the resultant material, which in turn affects the ${ }^{143} \mathrm{Nd} /{ }^{144} \mathrm{Nd}$ ratios by growth of radiogenic ${ }^{143} \mathrm{Nd}$. An underlying assumption is that Earth's mantle undergoes chondritic evolution, and deviations in initial ${ }^{143} \mathrm{Nd} /{ }^{144} \mathrm{Nd}$ ratios from the chondritic ratios (CHUR) expected for the ages of the rocks under study (the time $t$ ) provide information as to when a particular rock or reservoir separated from the mantle within the Earth's past. Positive $\varepsilon_{\mathrm{Nd}}$ values indicate derivation from depleted mantle sources; negative $\varepsilon_{\mathrm{Nd}}$ values indicated derivation from evolved older crust. The $\mathrm{Nd}$ model age, sometimes called the crust formation age, is an estimate of when important fractionations of $\mathrm{Sm}$ and $\mathrm{Nd}$ due to mantle melting occurred. Specifically, it is an estimate of when the initial ${ }^{143} \mathrm{Nd} /{ }^{144} \mathrm{Nd}$ of a sample was equal to that of its depleted mantle source, in other words, an estimate or "model" of the age of when a particular rock or reservoir was separated from the Earth's mantle, for which an assumed evolution has been calculated relative to CHUR. It is common practice in ANS Nd studies to exclude samples with high ${ }^{14} \mathrm{Sm} /{ }^{144} \mathrm{Nd}(>0.165)$ as such values cause unreliable model ages [23]. The importance of a model age is that the closer it is to the formation age as determined, for example, by U-Pb dating, the stronger is the indication that the sample is "juvenile," namely that the rock sample crystallized (in the case of an intrusive or extrusive rock) from material extracted from the mantle at about the same time or shortly before emplacement of the sample. It should be noted that the precision achievable in estimating $\mathrm{Sm}-\mathrm{Nd}$ model ages is less than can be achieved with the U$\mathrm{Pb}$ system and as a consequence $\mathrm{Nd}$ model ages tend to be reported as an order of magnitude greater than U-Pb ages, using the notation Ga (giga annum), and commonly without quoting errors (see Table 1). Thus Fig. (9) shows typical ANS Nd model ages as $0.95-0.68 \mathrm{Ga}$, whereas a typical U$\mathrm{Pb}$ age would be reported as $632 \pm 2 \mathrm{Ma}$, for example.

Oxygen isotopes in zircon grains are important for giving insight into the recycling of crustal material through orogenic cycles and the nature of source material [83]. Low 


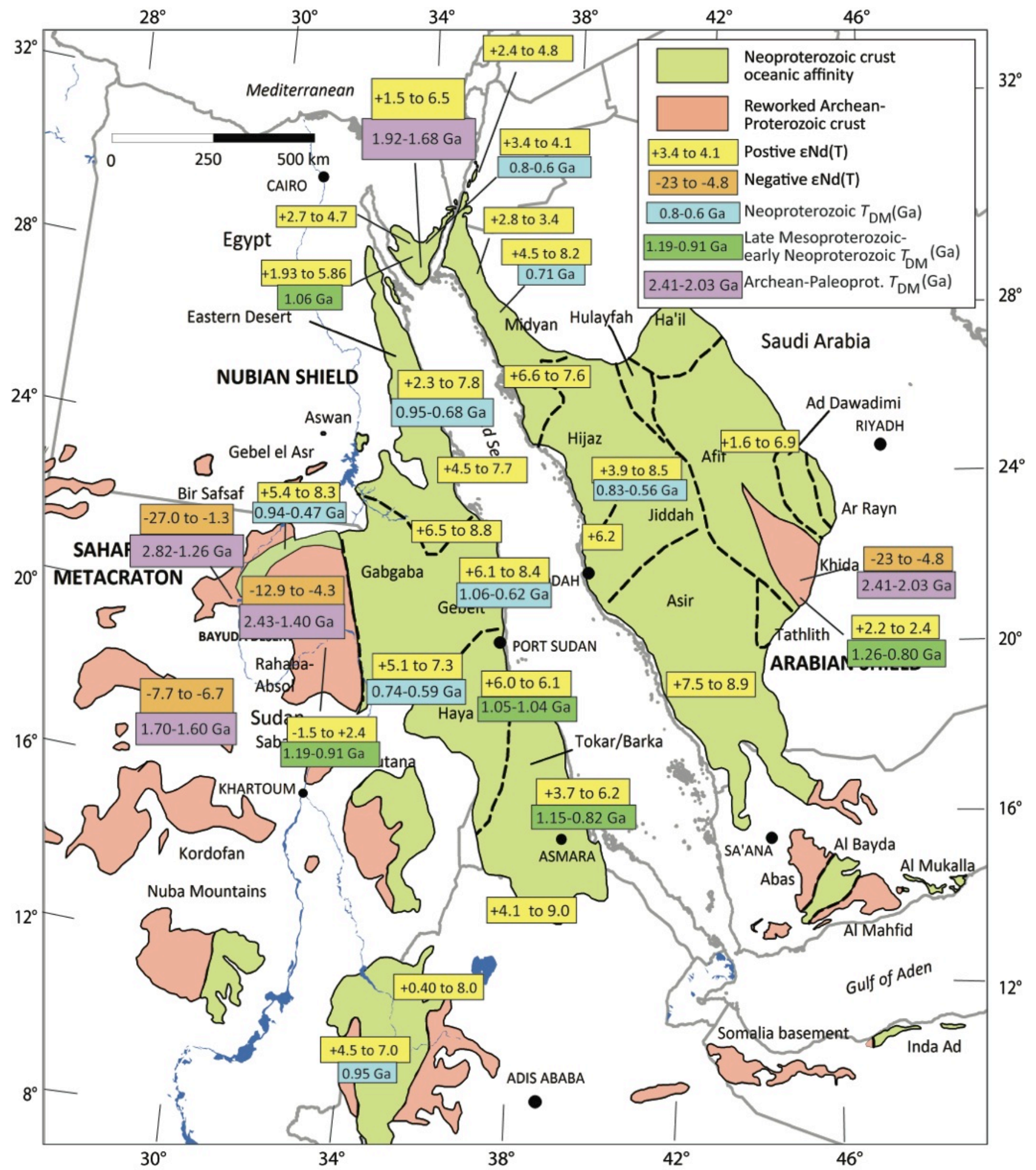

Fig. (9). Neodymium data for the Arabian-Nubian Shield. Data are sourced from compilations by [25] and [23] with additions from [5, 80, $36,37,72]$.

values of $\delta^{18} \mathrm{O}(\sim 5.3 \%)$ imply a mantle source or a crustal source not exposed to surface weathering, i.e. a juvenile source; higher values $(7.5-12 \%)$ imply incorporation into magma by subduction of material affected by near-surface weathering processes, i.e., recycling of crust. Hafnium isotopes also give an insight into the nature of magma sources and the extent of crustal recycling. Single-stage hafnium model ages $\left(\mathrm{Hf}-\mathrm{T}_{\mathrm{Dm}}\right.$ ) are calculated using measured ${ }^{176} \mathrm{Lu} /{ }^{177} \mathrm{Hf}$ of zircon relative to a model depleted mantle and give a minimum age for the source material of the magma from which the zircon crystallized. Two-stage Hf (crustal) model ages $\left(\mathrm{Hf}-\mathrm{T}_{\mathrm{Dm}}{ }^{\mathrm{c}}\right)$ provide information about the age of 
the zircon's parent magma assuming it was produced from a volume of average continental crust that was originally derived from a depleted mantle source. In addition, agecorrected epsilon values (غHf) are calculated using ${ }^{176} \mathrm{Hf} /{ }^{177} \mathrm{Hf}$ and ${ }^{176} \mathrm{Lu} /{ }^{177} \mathrm{Hf}$ measured on zircon and the apparent $\mathrm{U}-\mathrm{Pb}$ age of the same zircon or on a zircon population [49]. A study [73], for example, calculates Hf$\mathrm{T}_{\mathrm{Dm}}$ by means of a two-stage model whereby the ${ }^{176} \mathrm{Lu} /{ }^{177} \mathrm{Hf}$ of the zircon is used to first calculate back to the crystallization age determined by $\mathrm{U}-\mathrm{Pb}$ and then calculating back further to the DM using a fixed ${ }^{176} \mathrm{Lu} /{ }^{177} \mathrm{Hf}$ value for the given theoretical precursor reservoir. Different authors use different ${ }^{176} \mathrm{Lu} /{ }^{177} \mathrm{Hf}$ values. In the study by [73] three $\mathrm{T}_{\mathrm{Dm}} \mathrm{S}$ were calculated using values of 0.0093 corresponding to a felsic crust; 0.015 corresponding to an average crust; and 0.022 corresponding to a mafic crust. Using different values makes a difference in calculating Hf crustal model ages so that, together with analytical uncertainties and a lack of certitude in all instances about the assumption of mantle derivation, hafnium model ages may not be precise and may have realistic errors of at least $50 \mathrm{Ma}$ if not more.

Neodymium initial ratios and model ages for the northern part of the ANS are plotted in Fig. (9). The results elegantly show that the ANS is mostly juvenile crust. The surface rocks mostly yield positive $\varepsilon_{\mathrm{Nd}}(t)$ in the range $+1.5-8.9$ and model ages in the range $1.1-0.56 \mathrm{Ga}$, with local exceptions of $\varepsilon_{\mathrm{Nd}}(t)$ values as low as +0.4 and $T_{\mathrm{Dm}}$ as old as $1.26 \mathrm{Ga}$. Model ages in the shield average $0.85 \mathrm{Ga}$ [23], and when adjusted for time, most ages are broadly similar to the crystallization ages of the rocks examined, and the samples have initial ratio values consistent with derivation of the shield rocks from depleted mantle; that is, they are juvenile. Pre-Neoproterozoic crustal material identified by U-Pb crystallization ages flanks the ANS on the west and south, is locally present within the shield in the Khida terrane, and may have locally contributed to magma gneration in Sinai [114], southern Ethiopia [40] and parts of the eastern Arabian Shield [5]. These tracts have negative $\varepsilon_{\mathrm{Nd}}(t)$ values and Mesoproterozoic to Archean model ages averaging 2.1 $\mathrm{Ga}$ [23]. They consist of continental crust that predated the period of ensimatic magmatism responsible for creation of the ANS but, as demonstrated recently for the Saharan Metacraton [24], were extensively reworked during ANS orogenesis.

Hafnium isotope studies augment neodymium studies and give important additional information about crustal growth. On the basis of single zircon $\mathrm{U}-\mathrm{Pb}$ dating and neodymium isotopes, there is growing consensus that the Central Eastern Desert in Egypt is a tract of $\sim 750 \mathrm{Ma}$ juvenile volcanic-arc crust. Nonetheless, metasedimentary and metavolcanic rocks in Wadi El Dabbah, part of the oceanic arc sequence in the region [57], yield zircon hafnium isotope results that are difficult to interpret as only reflecting juvenile sources. The rocks have age corrected $\varepsilon \mathrm{Hf}$ values between +23.5 and -35 , single-stage Hf model ages $\left(\mathrm{T}_{\mathrm{DM}}\right)$ 0.78-3.3 Ga, and two-stage Hf model ages $\left(\mathrm{T}_{\mathrm{Dm}}{ }^{\mathrm{C}}\right)$ 0.78-3.8 $\mathrm{Ga}$ [49]. These results are variable but indicate that at least some of these magmas interacted with a pre-Neoproterozoic crustal source. The results are consistent with independently obtained evidence that the metasedimentary rocks contain Paleoproterozoic and Neoarchean detrital clasts and the metavolcanic rocks contain similarly aged zircon xenocrysts
[56]. The question, taken up in the Discussion section, then becomes one of explaining how old zircons became incorporated in $\sim 750$ sedimentary and volcanic rocks and how to integrate the evidence of a contribution from older crust with other evidence that the rocks were deposited in a juvenile oceanic setting.

Subtle variations in model ages, initial ratios, and isotopic values are consistent with division of ANS juvenile crust into tectonostratigraphic terranes [5]. ANS terrane divisions (Fig. 2) are mostly made on the basis of perceived differences in ages, structure, and stratigraphy across the shield, with terrane boundaries placed at ophiolite-decorated shear zones or inferred sutures $[21,25]$. $\mathrm{Nd} \mathrm{T}_{\mathrm{Dm}}$ model ages $>0.9 \mathrm{Ga}$ characterize the northernmost and southern ANS, whereas $<0.9$ Ga model ages characterize the central ANS [23]. As shown by the plot of data in Fig. (9), however, model age differences across the shield may be more varied than a simple binary division. A review [5] of spatial variations in published $\mathrm{Nd}, \mathrm{Pb}, \mathrm{Sr}$, and $\mathrm{O}$ isotopic data, coupled with geochronologic and geologic information, leads to a proposed re-evaluation of terrane models for the Arabian Shield, suggesting increasing the number of terranes to fifteen. It would be timely for the acquisition of additional data from parts of ANS not yet isotopically studied to confirm or modify such structural divisions.

As a concluding comment in this section of the paper, it is interesting to note that the $\mathrm{Nd}$ isotopic compositions of mafic and intermediate lower crustal and mantle xenoliths collected from Cenozoic alkali basalt erupted through basement rocks in western Arabia strongly support a Neoproterozoic juvenile origin for the ANS lower crust [27, $84,85]$. Ten lower crustal xenoliths from western Saudi Arabia have model ages between $0.95-0.65$ Ga with a mean of $0.76 \mathrm{Ga}$. They also have $\varepsilon_{\mathrm{Nd}}(750 \mathrm{Ma})$ between +1.5 and +7.3 with a mean of +5.5 , consistent with the values expected for the depleted mantle at that time. Upper mantle xenoliths have uniformly positive $\varepsilon_{\mathrm{Nd}}$, consistent with juvenile Neoproterozoic upper mantle, ranging between $+5.8-+8.7$ for Saudi Arabian clinopyroxene samples [84, 86] and between of $+0.6-+1.18$ for Syrian samples [87]. These data suggest that the ANS upper mantle as well as the lower crust consists of juvenile Neoproterozoic material isotopically similar to the upper crust in the shield. An alternative interpretation applied to samples from central Saudi Arabia [88] is that the xenoliths were cumulates related to Neogene alkaline host lavas. On balance it would seem, however, that the ANS lower crust-upper mantle was created during the Neoproterozoic at about the same time as the crustal processes that created the supracrustal rocks [27]. The ANS lower crust and upper mantle persisted through the Phanerozoic and, despite Cenozoic mantle upwelling and some degree of partial melting in connection with Red Sea rifting, mantle xenoliths retain a primitive mantle-like composition and appear to record the ancient $(>1.2 \mathrm{Ga})$ isotopic signature of the depleted upper mantle that was the protolith of the Arabian lithospheric mantle [89].

\section{MARGINS OF THE ANS}

One direct outcome of the expanding geochronologic and isotopic databases for the ANS is better definition of the margins of the shield. Overall, the ANS comprises a tract of 
Neoproterozoic juvenile oceanic crust at the northern end of the East African Orogen. In places, the distinction between ANS juvenile crust and adjacent older crust is clearly evident; the margin of the ANS can be drawn with confidence and the structural and tectonic processes that caused the two types of crust to be juxtaposed can be analyzed. In other places however, older crust is structurally intercalated with juvenile crust, is thoroughly reworked, or is concealed beneath Phanerozoic strata. Current views about the limits of Neoproterozoic juvenile oceanic crust making up the shield are illustrated in Figs. $(\mathbf{1}, \mathbf{2})$.

The broadest expanse of the ANS is in Sudan and Saudi Arabia. To the south, the shield tapers and terminates in southern Kenya and northern Tanzania against high-grade rocks of the Mozambique Belt. To the north, Neoproterozoic crustal rocks disappear beneath Phanerozoic of the Arabian Plate and northern African Plate. Limited bore-hole data yield evidence of Ediacaran strata at a depth of $\sim 3500 \mathrm{~m}$ in northern Israel [90], and lower-crustal and upper-mantle xenoliths brought to the surface in Cenozoic eruptions indicate juvenile Neoproterozoic basement as far north as northern Jordan and Syria. There is no direct evidence of Neoproterozoic juvenile crust farther north, although it is generally assumed that such crust extends to the northern limit of the Arabian Plate in southern Turkey. Neoproterozoic crust of Gondwanan origin crops out as structural enclaves, or peri-Gondwana domains, in the Eurasian Plate - in the Alpine Belt of southern Europe, the Balkans, Turkey, Georgia, and interior Iran (e.g., [91]). The exact details of the history of these domains is not fully known and many questions and problems remain (see reviews $[92,93])$. They imply, however, that the original northern limit of the ANS should be sought in what, during the Phanerozoic, became accreted terranes on the northern margin of Tethys and are now incorporated in Eurasia.

\section{Southwestern Margin of ANS}

The location of the western margin of the ANS is reasonably well constrained and intermittently exposed as ophiolite-decorated shear zones in the south and as a shear zone and an indentation in older crust farther north (Figs. 1, 2). It extends south from the Bayuda Desert through the eastern part of the Nuba Mountains into Kenya and northern Tanzania. The Athi shear zone [4, 94] juxtaposes the Archean Congo-Tanzania Craton and Eastern Granulite Complex of the Mozambique Belt with juvenile ANS crust of oceanic affinity. The Eastern Granulite Complex [95, 96] consists of of meta-igneous and metasedimentary rocks that yield 900-700 Ma formation ages, $\sim 1000 \mathrm{Ma}$ Nd model ages, and 650-620 Ma metamorphic ages [97]. The rocks are inferred to be broadly coeval with typical Neoproterozoic ANS juvenile crust [98], but are differentiated by their high grade of metamorphism, and are incontact with the ANS because of westward thrust stacking during closure of the Mozambique Ocean [3]. The southern tip of the ANS is represented by a belt of 955-845 Ma old subduction-related amphibolites and gneisses adjacent to the Galana-Athi shear zone [99].
The western ANS margin in central Sudan is exposed along a shear zone in the Nuba Mountains. The shear zone marks a fossil plate boundary [100], separating high-grade gneisses belonging to the Saharan Metacraton on the west from a low-grade volcanosedimentary ANS sequence on the east. The gneisses are chiefly quartzofeldspathic and probably represent sedimentary, granitic, and granodioritic protoliths metamorphosed to the amphibolite grade. They yield $\mathrm{Nd}$ model ages of $\sim 2.0 \mathrm{Ga}, 1 \mathrm{Ga}$, and $0.95 \mathrm{Ga}$ and $\mathrm{Rb}-$ $\mathrm{Sr}$ ages between 684 and $514 \mathrm{Ma}$ [100]. The suture zone itself comprises the Kabus ophiolitic mélange, a $\sim 10 \mathrm{~km}$ wide and $70 \mathrm{~km}$ long belt of imbricated lenses, blocks, slabs, and sheets of serpentinite in a matrix of sheared graphitic phyllite, sericite phyllite, and slate. Low-grade juvenile volcanosedimentary rocks east of the ophiolite mélange are polydeformed chlorite schists (mafic metavolcanic rocks); quartzofeldspathic schists (felsic metavolcanic rocks); quartz and quartz mica schists (psammites); metacherts and cherty marbles; quartzites; and graphitic schists (pelite). The Kabus Suture is interpreted as the site of closure of a marginal basin between the Saharan Metacraton and the ANS [100]. Mafic lavas plot in the arc lava and arc/MORB fields, and together with the volcanosedimentary rocks, are modeled as having formed in a west-dipping subduction system at the eastern edge of the marginal basin. Closure of the basin led to collision between juvenile ANS rocks and continental crust resulting in east-directed thrusting of ophiolitic rocks and continental crust over volcanosedimentary rocks of the ANS [100].

\section{Saharan Metacraton Margin}

The most continuous exposure of the ANS western margin is a contact with the Saharan Metacraton along the eastern edge of the Bayuda Desert in northern Sudan (Fig. 10). The exact placement of the contact is debated but is clarified by recent mapping and geochronologic and isotopic sampling, and the area is a prime example of a situation in which geochronologic and isotopic data help to delineate a fundamental geologic boundary. Overall, the contact is referred to as the Keraf suture [101], an arc-continental boundary named after a N-S sinistral subvertical shear zone. The contact is a long-lived zone of tectono-thermal activity at the western margin of the ANS, reflecting an early $\sim 750$ Ma period of orogenesis and later $\sim 650-600$ Ma sinistral shearing during final oblique transpressive convergence of eastern and western Gondwana and accretion of ANS to the Saharan Metacraton [101]. The Atmur-Delgo suture is a westerly-trending fold and thrust belt forming a reentrant of juvenile ANS rocks in the Saharan Metacraton that interrupts the otherwise northerly trend of the ANS/Saharan Metacraton contact.

The Saharan Metacraton is a large tract of suspect Archean-Paleoproterozoic-Mesoproterozoic rocks, intermittently exposed in north-central Africa and the Saharan Desert and extending into Egypt and Sudan. The term "metacraton" refers to a craton that has been remobilized during an orogenic event but is still recognizable through its rheological, geochronological and isotopic characteristics 

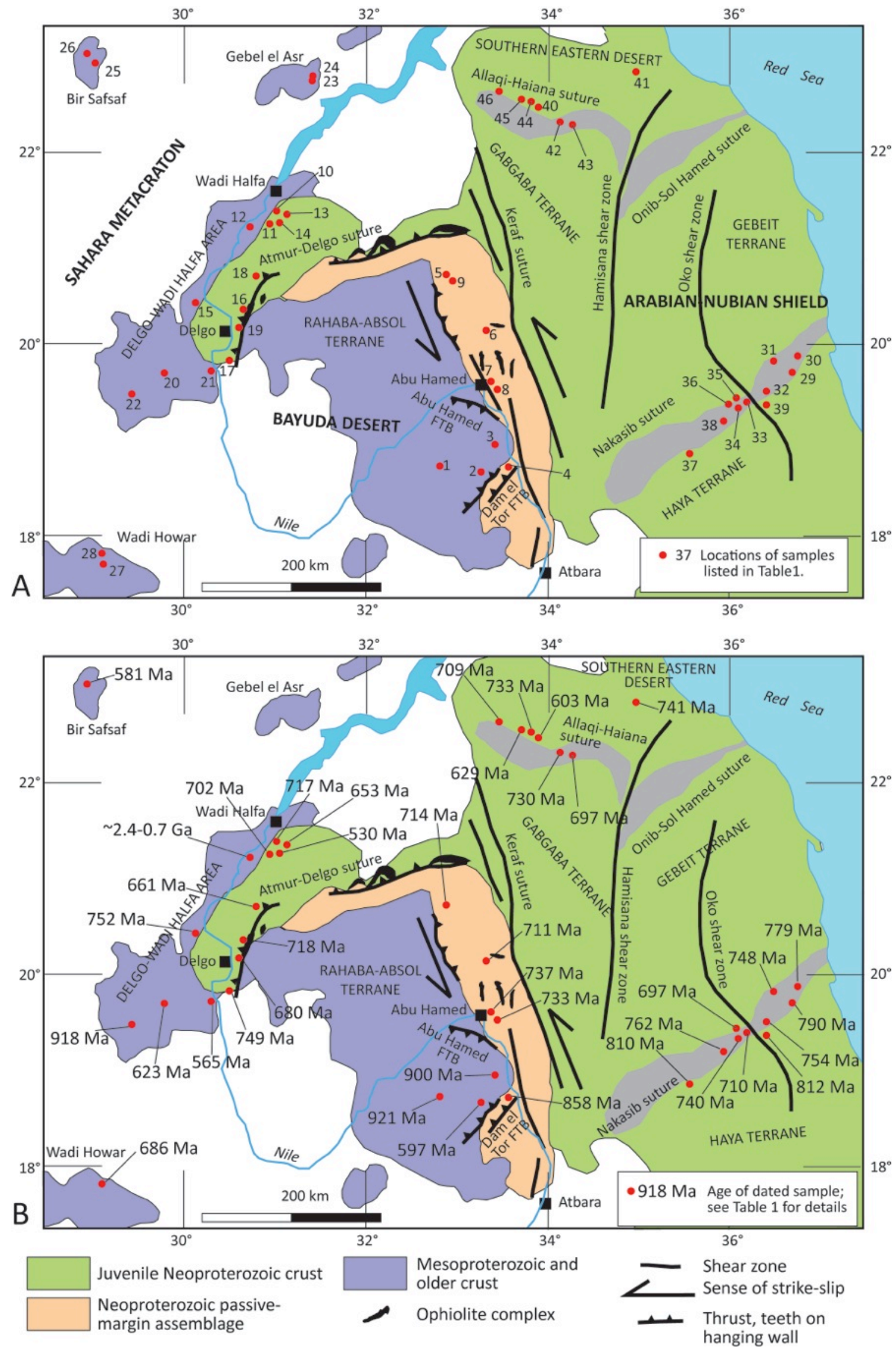

Fig. (10). (A, B) Geochronologic and isotopic data for the contact between the Arabian-Nubian Shield and the Saharan Metacraton as exposed in the Bayuda Desert and Delgo-Wadi Halfa area. (A) Sample locations; (B) Formation and metamorphic ages (see Table 1 for sources, sample descriptions, and dating methods). 


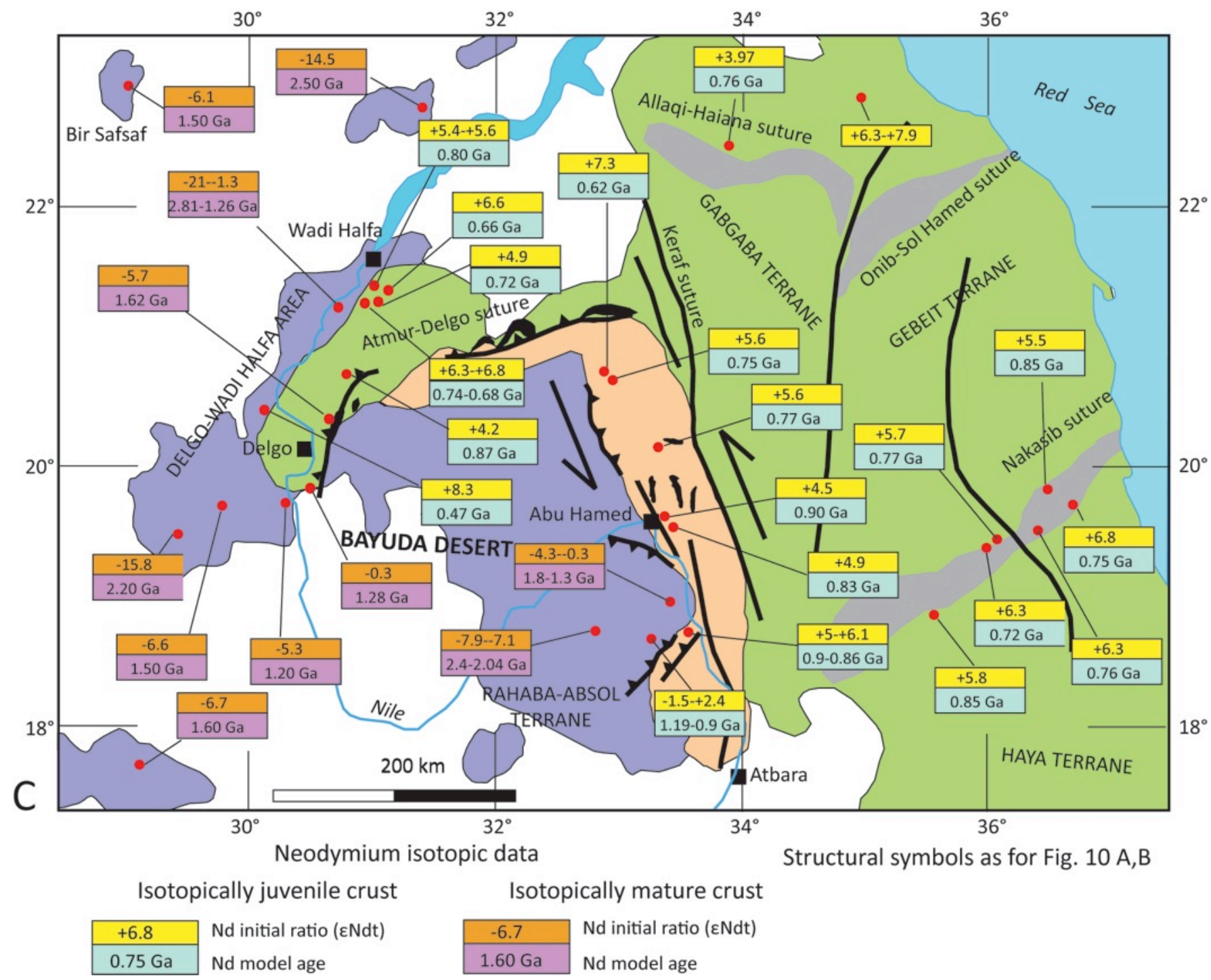

Fig. (10C). Neodymium initial ratios and model ages for the same area as illustrated in Fig. (10A, B). See Table 1 for sources, sample descriptions, and dating methods.

[24]. Because much of the basement of North Africa is covered by Phanerozoic strata and Cenozoic alluvium and eolian deposits, the exact age and composition of the metacraton rocks are not well established. It is certain, however, that the metacraton includes significant volumes of Neoproterozoic (Pan-African) migmatitic gneiss, most likely reworked from older rocks. It is also clear that, in the vicinity of the ANS, sparse Archean, Paleoproterozoic, and Mesoproterozoic continental rocks were remobilized during the Neoproterozoic by deformation, metamorphism, emplacement of igneous bodies, and probable local rifting and development of oceanic basins [24]. In the immediate vicinity of the Keraf suture, the Saharan Metacraton includes pre-ANS medium- to high-grade metasedimentary schists, paragneiss, and orthogneiss exposed in the Delgo-Wadi Halfa area west and northwest of the Atmur-Delgo suture (or reentrant) $[102,103]$ and in the Bayuda Desert where the rocks are referred to as the Rahaba-Absol terrane [72]. The Rahaba Series comprises quartzo-feldspathic gneiss; the Absol Series consists of mica schist, amphibolite, and hornblende gneiss. The Delgo-Wadi Halfa rocks consist of granitic gneiss and migmatite with minor intercalations of calc-silicates, marble, amphibolite, and conglomerate. These rocks reflect periods of crustal growth at $\sim 2.4,2.0,1.8-1.6$, and 1.2-1.0 Ga but they were metamorphosed under upper amphibolite-facies conditions up to incipient migmatization at about $720 \mathrm{Ma}$ and intruded by Neoproterozoic syn-tectonic and post-tectonic granitoids [103].

However, because of reworking, interpreting geochronologic and isotopic data in this region is complicated. For example, the El Melgai gneiss in the Rahaba Series is metamorphosed pelite (Table 1, location 1; Fig. 10A) yielding zircon SIMS ages between $2.6 \mathrm{Ga}$ and $829 \mathrm{Ma}[71,72]$. The Archean and Paleoproterozoic ages are interpreted as the ages of zircon grains and zircon cores from the source region of the pelitic clastic material; a late Mesoproterozoic age in the gneiss, an inherited grain of 1.06 $\mathrm{Ga}$, defines the maximum deposition age; and zircon rims with an age of $921 \pm 10 \mathrm{Ma}$ are interpreted as metamorphic zircon growth on older cores. Taking the $\mathrm{Nd}$ isotopic data into account, the results are interpreted to mean that the El 
Table 1. Geochronologic and Isotopic Data Helping to Define the Contact Between the Saharan Metacraton and the ArabianNubian Shield

\begin{tabular}{|c|c|c|c|c|c|c|c|}
\hline No. & Age (Ma) & Name & Sample \# & Dating Method & Nd Age & Nd Initial Ratio & Source \\
\hline 1 & $921 \pm 10$ & $\begin{array}{l}\text { El Melgai gneiss, } \\
\text { Rahaba Series }\end{array}$ & $12-2$ & $\begin{array}{l}\text { U-Pb zircon SIMS } \\
\text { (SHRIMP) }\end{array}$ & $2.4-2.04 \mathrm{Ga}$ & -7.9 to -7.1 & {$[72]$} \\
\hline 3 & $900 \pm 9$ & Absol ganite & $10-8 \mathrm{~A}$ & $\begin{array}{l}\text { U-Pb zircon SIMS } \\
\text { (SHRIMP) }\end{array}$ & $1.83-1.3 \mathrm{Ga}$ & -4.3 to -0.3 & {$[72]$} \\
\hline 5 & $714 \pm 7$ & Diorite & 1.1 & ${ }^{207} \mathrm{~Pb} /{ }^{206} \mathrm{~Pb}$ zircon evap. & $0.62 \mathrm{Ga}$ & $+7.3(\mathrm{t}=714)$ & [104] \\
\hline 6 & $711 \pm 5$ & Granodiorite & 6.9 & ${ }^{207} \mathrm{~Pb} /{ }^{206} \mathrm{~Pb}$ zircon evap. & 0.77 & $+5.6(\mathrm{t}=711)$ & [104] \\
\hline 7 & $737 \pm 5$ & Orthogneiss & 11.13 & ${ }^{207} \mathrm{~Pb} /{ }^{206} \mathrm{~Pb}$ zircon evap. & 0.90 & $+4.5(\mathrm{t}=737)$ & [104] \\
\hline 11 & $702 \pm 18$ & $\begin{array}{c}\text { Arusa ring complex } \\
\text { (microgranite to syenite) }\end{array}$ & $169 \mathrm{~S}, 171 \mathrm{~S}, 172 \mathrm{~S}$ & ${ }^{207} \mathrm{~Pb} /{ }^{206} \mathrm{~Pb}$ zircon evap. & $0.74-0.68$ & $\begin{array}{c}+6.3 \text { to }+6.8(t=707 \\
\mathrm{Ma})\end{array}$ & {$[36]$} \\
\hline 12 & $\sim 2.4-0.7 \mathrm{Ga}$ & Duwaishat gneiss & WH7-15 & ${ }^{207} \mathrm{~Pb} /{ }^{206} \mathrm{~Pb}$ zircon evap. & $2.81-1.26 \mathrm{Ga}$ & -21 to $-1.3(\mathrm{t}=700 \mathrm{Ma})$ & [103] \\
\hline 13 & $653 \pm 20$ & Metabasalt and metarhyolite & WH 1-6 & $\mathrm{Rb}-\mathrm{Sr}$ whole rock & $0.66 \mathrm{Ga}$ & $+6.6(\mathrm{t}=650 \mathrm{Ma})$ & [103] \\
\hline 14 & $530 \pm 10$ & Alkali granite & WH20-28 & Rb-Sr whole rock & $0.72 \mathrm{Ga}$ & $+4.9(\mathrm{t}=530 \mathrm{Ma})$ & [103] \\
\hline 15 & $752 \pm 49$ & Gabbro from Delgo ophiolite & ASS27 & Sm-Nd isochron & 0.47 & +8.3 & [102] \\
\hline 16 & $718 \pm 11$ & Syn-tectonic tonalite & NGD & ${ }^{207} \mathrm{~Pb} /{ }^{206} \mathrm{~Pb}$ zircon evap. & $1.62 \mathrm{Ga}$ & -5.7 & [102] \\
\hline 17 & $749 \pm 12$ & $\begin{array}{l}\text { Syn-tectonic granodiorite to } \\
\text { tonalite }\end{array}$ & ITGS & ${ }^{207} \mathrm{~Pb} /{ }^{206} \mathrm{~Pb}$ zircon evap. & $1.28 \mathrm{Ga}$ & -0.3 & [102] \\
\hline 23 & No meaning-ful age & Tonalite gneiss & GEA-MG4 & & 2.50 & $-14.5(\mathrm{t}=700 \mathrm{Ma})$ & [11] \\
\hline 24 & No meaning-ful age & Tonalite gneiss & GEA-MG8 & & 1.90 & $-13.1(\mathrm{t}=700 \mathrm{Ma})$ & [11] \\
\hline 25 & $\sim 590$ & Bir Safsaf orthogneiss & BSSOG6a & Rb-Sr w.r. & 1.50 & $-6.1(\mathrm{t}=580 \mathrm{Ma})$ & [11] \\
\hline 26 & $581 \pm 75$ & Bir Sfasaf granodiorite & BSSGD4 & Rb-Sr w.r. & 1.50 & $-7.0(\mathrm{t}=580 \mathrm{Ma})$ & [11] \\
\hline 27 & $686 \pm 26$ & Wadi Howar migmatite & WH-M3 & Rb-Sr w.r. & 1.60 & $-6.7(\mathrm{t}=690 \mathrm{Ma})$ & [11] \\
\hline 28 & $\sim 700$ & Wadi Howar tonalite gneiss & WH-TG1 & Rb-Sr w.r. & 1.70 & $-7.7(\mathrm{t}=700 \mathrm{Ma})$ & {$[11]$} \\
\hline 29 & $790 \pm 2$ & Arbaat rhyolite & $48-1$ & $\begin{array}{l}\text { Conventional } \\
\text { U-Pb zircon }\end{array}$ & 0.75 & $+6.8(\mathrm{t}=790 \mathrm{Ma})$ & [137] \\
\hline 30 & $779 \pm 3$ & Arbaat pluton & $45-5$ & $\begin{array}{l}\text { Conventional } \\
\text { U-Pb zircon }\end{array}$ & 0.71 & $+7.0(\mathrm{t}=780 \mathrm{Ma})$ & [137] \\
\hline 31 & $748 \pm 3$ & Meritri pluton & $12-3 \mathrm{~A}$ & $\begin{array}{l}\text { Conventional } \\
\text { U-Pb zircon }\end{array}$ & 0.85 & +5.5 & [137] \\
\hline 32 & $754 \pm 3$ & Tendily pluton & $32-2 \mathrm{~A}$ & $\begin{array}{l}\text { Conventional } \\
\text { U-Pb zircon }\end{array}$ & 0.76 & +6.3 & [137] \\
\hline 33 & $710 \pm 3$ & Hantouly pluton & $32-3 \mathrm{~A}$ & $\begin{array}{l}\text { Conventional } \\
\text { U-Pb zircon }\end{array}$ & 0.72 & +6.4 & [137] \\
\hline 34 & $740 \pm 3$ & Luggag pluton & $36-3 \mathrm{~A}$ & $\begin{array}{l}\text { Conventional } \\
\text { U-Pb zircon }\end{array}$ & 0.69 & +7.0 & [137] \\
\hline
\end{tabular}


(Table 1) contd....

\begin{tabular}{|c|c|c|c|c|c|c|c|}
\hline No. & Age (Ma) & Name & Sample \# & Dating Method & Nd Age & Nd Initial Ratio & Source \\
\hline 35 & $697 \pm 5$ & Shalhout pluton & $25-1 \mathrm{~A}$ & Rb-Sr w.r. & 0.77 & +5.7 & {$[137]$} \\
\hline 36 & & Unnamed pluton & $28-1 \mathrm{~A}$ & & 0.72 & $+6.3(\mathrm{t}=700 \mathrm{Ma})$ & {$[137]$} \\
\hline 37 & $810 \pm 12$ & Adaiamet pluton & A8 & ${ }^{207} \mathrm{~Pb} /{ }^{206} \mathrm{~Pb}$ zircon evap. & 0.85 & +5.8 & {$[137,138]$} \\
\hline 38 & $762 \pm 23$ & Agwampt pluton & AW6 & ${ }^{207} \mathrm{~Pb} /{ }^{206} \mathrm{~Pb}$ zircon evap. & 0.73 & +6.8 & {$[137,138]$} \\
\hline 39 & $812 \pm 18$ & Tala granodiorite & OSZ-13b & ${ }^{207} \mathrm{~Pb} /{ }^{206} \mathrm{~Pb}$ zircon evap. & 1.76 & +6.8 & {$[137,138]$} \\
\hline 40 & $603 \pm 14$ & Um Ara granite & & $\begin{array}{c}\text { U-Pb SIMS } \\
\text { (SHRIMP) zircon }\end{array}$ & $0.76 \mathrm{Ga}$ & +3.97 & {$[139]$} \\
\hline 41 & $741 \pm 21$ & Gebel Gerf ophiolite gabbro & & ${ }^{207} \mathrm{~Pb} /{ }^{206} \mathrm{~Pb}$ zircon evap. & & $+6.3-+7.9$ & {$[140,141]$} \\
\hline 42 & $730 \pm 6$ & Wadi Abu-Fas gabbro & $\mathrm{AF}-4$ & $\begin{array}{l}\text { U-Pb zircon SIMS } \\
\text { (SHRIMP) }\end{array}$ & & & {$[42]$} \\
\hline 43 & $697 \pm 5$ & Jabal Moqsim gabbro & MKS-1 & $\begin{array}{l}\text { U-Pb zircon SIMS } \\
\text { (SHRIMP) }\end{array}$ & & & {$[42]$} \\
\hline 44 & $733 \pm 7$ & Wadi Shilman metadacite & SHI-3 & $\begin{array}{l}\text { U-Pb zircon SIMS } \\
\text { (SHRIMP) }\end{array}$ & & & {$[42]$} \\
\hline 45 & $629 \pm 5$ & Wadi Shilman granodiorite & SHI-1 & $\begin{array}{l}\text { U-Pb zircon SIMS } \\
\text { (SHRIMP) }\end{array}$ & & & {$[42]$} \\
\hline 46 & $709 \pm 4$ & $\begin{array}{l}\text { Wadi um Ashirah } \\
\text { quartz diorite }\end{array}$ & ASH-1 & $\begin{array}{l}\text { U-Pb zircon SIMS } \\
\text { (SHRIMP) }\end{array}$ & & & {$[42]$} \\
\hline 47 & $702 \pm 27$ & Calc-silicate whole rock & G 385 & $\begin{array}{c}\mathrm{Sm}-\mathrm{Nd} \\
(\mathrm{MSWD}=0.8)\end{array}$ & & -2.2 & {$[102]$} \\
\hline 48 & $770 \pm 108$ & Calc-silicate whole rock & 93 & $\begin{array}{c}\mathrm{Sm}-\mathrm{Nd} \\
(\mathrm{MSWD}=0,1)\end{array}$ & & -2.9 & [102] \\
\hline
\end{tabular}

Melgai gneiss is a supracrustal metasedimentary rock deposited about $1 \mathrm{Ga}$ that was derived from an ArcheanPaleoproterozoic source region and metamorphosed in the amphibolite facies at about $920 \mathrm{Ma}$ [72]. The nearby Absol granite (location 3) was emplaced $\sim 900 \mathrm{Ma}$, but the negative $\varepsilon_{\mathrm{Nd}}$ values (-4.3 to -0.3$)$ and $1.8-1.3 \mathrm{Nd}$ model ages indicate that it was derived from Archean-Paleoproterozoic source material [72]. The Duwaishat gneiss (location 12) yields an $\mathrm{Rb}$-Sr errorchron of $\sim 2.5 \mathrm{Ga}$ and ${ }^{207} \mathrm{~Pb} /{ }^{2068} \mathrm{~Pb}$ evaporation ages between $\sim 2.4 \mathrm{Ga}$ and $720 \mathrm{Ma}$, and appears to be part of a pre-ANS crust that was affected by later tectono-thermal events. Nubian Desert gneiss (location 22), which yields an $\mathrm{Rb}$-Sr errorchron of $918 \pm 40$ Ma but has a strongly negative $\varepsilon_{\mathrm{Nd}}$ value (-15.8) and a Paleoproterozoic model age (2.20 $\mathrm{Ga}$ ), is interpreted as a Paleoproterozoic rock that was metamorphosed during an early Neoproterozoic tectonothermal event similar to the $921 \pm 10$ Ma metamorphic event in the El Melgai gneiss. Neoproterozoic granites close to Delgo (location 20,21) were emplaced about $623 \mathrm{Ma}$ and $565 \mathrm{Ma}$, but have negative $\varepsilon_{\mathrm{Nd}}$ values and Mesoproterozoic $\mathrm{Nd}$ model ages and were evidently derived from Mesoproterozoic sources [102]. Overall, these rocks represent the easternmost sector of the Saharan Metacraton in a region where the metacraton was extensively thermally reworked and intruded during the Neoproterozoic and structurally reworked by folding and shearing during collision with the ANS [101].

The Rahaba-Absol terrane (Fig. 10) is flanked on the east and north by carbonate-rich turbidites and paragneisses that have Neoproterozoic formation and metamorphic ages and juvenile isotopic characteristics. The turbidite sequence, variously referred to as the Keraf petrotectonic assemblage
[104] and the Bailateb Group [105], is interpreted as a passive-margin sedimentary assemblage deposited on a paleoslope shallowing westward. The paragneisses, referred to as the Kurmut Series [72], are interpreted as having arcrelated protoliths. The available data suggest that the Kurmut Series paragneiss protoliths formed $\sim 850 \mathrm{Ma}$ whereas the passive-margin assemblage probably formed before $\sim 735$ Ma [72,104]. Epidote-biotite gneiss in the paragneiss assemblage has metaluminous to slightly peraluminous affinity, and its trace-element signature is akin to subduction-related I-type magma from a relatively primitive oceanic arc [71]. It is inferred that the gneisses were derived from a subduction-related magmatic event in an intraoceanic arc system [72]. The Keraf petrotectonic assemblage and Bailateb Group comprise high- to medium-grade gneiss, siliciclastic, and carbonate-rich metasediments intercalated with metabasalt, microdiorite, and ophiolite nappes intruded by calc-alkaline, medium-K, metaluminous and I-type diorite and granodiorite with subduction-related trace-element signatures [104]. Where sedimentary structures are preserved, the rocks show evidence of both shallow- and deep-water, turbiditic deposition.

A sample of Kurmut Series epidote-biotite orthogneiss from the Dam el Tor fold-thrust belt (sample 4; Table 1) has a U-Pb Concordia age of $858 \pm 7$ Ma (MSWD $=0.65$ ), interpreted as the formation age of a rhyodacitic volcanic or subvolcanic precursor [72]. The gneiss has positive $\varepsilon \mathrm{Nd}$ values of +5.6 to +6.1 and $\mathrm{Nd}$ model ages of $900-860 \mathrm{Ma}$, evincing a juvenile origin. Its $\mathrm{Sr}$ and $\mathrm{Pb}$ isotopic characteristics substantiate a juvenile setting and indicate subduction-related magmatism with no involvement of older pre-Neoproterozoic crust. The timing of metamorphism and 
deformation of the Kurmut Series is constrained by an Sm$\mathrm{Nd}$ isochron of $806 \pm 19 \mathrm{Ma}$ obtained from amphibolites and epidote-biotite [71] and is inferred to be contemporary with the onset of accretion between the Kurmut arc and Saharan Metacraton [72]. Orthogneiss in the Bailateb Group (samples $7,8)$ yields relatively well constrained ${ }^{207} \mathrm{~Pb} /{ }^{206} \mathrm{~Pb}$ zircon evaporation ages of $737 \pm 5 \mathrm{Ma}$ and $737 \pm 18 \mathrm{Ma}$ [104]. The gneiss has been metamorphosed to upper amphibolite facies and may represent highly deformed plutonic rocks emplaced deep in the crust postdating deposition of their metasedimentary host rocks [104]. If the ages are protolith crystallization ages, they imply that the Bailateb Group is older than $\sim 735 \mathrm{Ma}$. The gneisses have positive $\varepsilon_{\mathrm{Nd}}$ values of +4.5 to +4.9 and model ages of $0.9-0.83$ Ga consistent with a juvenile ANS setting. Diorite and granodiorite plutons that intrude the Bailateb Group (samples 5, 6) yield ${ }^{207} \mathrm{~Pb} /{ }^{206} \mathrm{~Pb}$ zircon evaporation ages of $714 \pm 7$ and $711 \pm 5 \mathrm{Ma}$ and have $\varepsilon_{\mathrm{Nd}}$ values of +7.3 and +5.6 and $\mathrm{T}_{\mathrm{Dm}} 0.62 \mathrm{Ga}$ and $0.77 \mathrm{Ga}$. It is not certain whether these ages are protolith crystallization ages or high-grade metamorphic (upper amphibolite- to granulite facies) ages, but they are indistinguishable from values for typical juvenile ANS rocks farther east [104].

Overall, the Kurmut Series and its equivalents in the Bailateb Group and Keraf petrotectonic assemblage are interpreted as juvenile additions to the crust [104], and the lack of older components in the Kurmut Series suggests that it formed some distance away from any continental margin [72]. The rocks are viewed as part of the ANS and represent the onset of ANS magmatism and sedimentation in this part of the Mozambique Ocean. The Kurmut Series represents the oldest ANS rocks in this part of the shield and result from a late Tonian arc-subduction event east of the Saharan Metacraton followed 50 million years later by accretion of the arc with the craton. The Bailateb Group metasedimentary rocks appear to reflect deposition of a thick sequence of carbonate and siliciclastic rocks by $730 \mathrm{Ma}$ at the latest on the eastern flank of the Kurmut crust. Both Kurmut and Bailateb rocks were deposited in a juvenile environment as part of the ANS, and the western margin of the ANS in this location is the structural contact between the Kurmut Series and the Rahaba-Absol terrane.

The reentrant along the Atmur-Delgo suture comprises low- to middle amphibolite-facies biotite and biotitehornblende gneiss, amphibolite, quartzite, quartzitic schist, mica schist, calc-silicate rock, marble, and disrupted ophiolitic complexes [106]. The rocks are thrust south over the Rahaba-Absol terrane so their exact stratigraphic relationships are debated. The protoliths of the Atmur-Delgo suture metamorphic rocks have middle Cryogenian ages and juvenile isotopic characteristics. They yield early Neoproterozoic $\mathrm{Nd}$ model ages and positive $\varepsilon_{\mathrm{Nd}}$ values, and the assemblage is intruded by granitoids that only record middle to late Neoproterozoic (Pan-African) orogenic events. Despite penetrating the Saharan Metacraton, the assemblage is considered to be part of the Arabian-Nubian Shield [72], constituting a middle Cryogenian assemblage of juvenile oceanic ANS-type rocks that formed in a possible reentrant of the Mozambique Ocean. A sample of gabbro from ophiolite northeast of Delgo (sample 15 in Table 1) yields an $\mathrm{Sm}-\mathrm{Nd}$ age of $752 \pm 48 \mathrm{Ma}\left[\varepsilon_{\mathrm{Nd}}(752 \mathrm{Ma})=8.4\right]$, which is interpreted as the age of oceanic crust in the reentrant [102]. ${ }^{207} \mathrm{~Pb} /{ }^{206} \mathrm{~Pb}$ zircon evaporation ages of $717 \pm 10 \mathrm{Ma}$ and
$702 \pm 18 \mathrm{Ma}($ samples 10,11$)\left(\varepsilon_{\mathrm{Nd}}=+5.4\right.$ to $+6.8 ; \mathrm{T}_{\mathrm{Dm}}=0.8-$ $0.68 \mathrm{Ga}$ ) obtained from post-tectonic A-type ring complexes suggests closure of the reentrant by $\sim 720-710 \mathrm{Ma}$ [36]. Metavolcanic rocks south of Wadi Halfa (sample 13) yield a $\mathrm{Rb}-\mathrm{Sr}$ isochron of $653 \pm 20 \mathrm{Ma}\left[\varepsilon_{\mathrm{Nd}}(650 \mathrm{Ma})=+6.6 ; \mathrm{T}_{\mathrm{Dm}}=\right.$ $0.66 \mathrm{Ga}]$ interpreted as the approximate time of volcanism [103]. Imprecise Sm-Nd whole-rock ages of $702 \pm 27 \mathrm{Ma}$ and $770 \pm 108 \mathrm{Ma}$ obtained from calc-silicate rocks close to Delgo (samples 47, 48) are interpreted as the timing of isotopic equilibration during peak metamorphism in the region [102] although this interpretation is problematic if the undeformed A-type ring complexes mean that deformation had ceased by $\sim 715 \mathrm{Ma}$. The reported negative $\varepsilon_{\mathrm{Nd}}$ values for samples 47 and $48(-2.2,-2.9)$ are also problematic in contrast to the juvenile positive values of other rocks in the Atmur-Delgo reentrant; perhaps the calc-silicate rocks contain a component of older material from the Saharan Metacraton, unique among other rocks of the reentrant. Overall, it is considered that the rocks of the reentrant were deposited during a Cryogenian opening and closing of an oceanic basin at the eastern margin of the Saharan Metacraton [106]. Closure resulted in the formation of south-vergent nappes of ophiolite mélange thrust over a tapering wedge of older passive margin sediments and the pre-ANS Rahaba-Absol terrane [106]. Metamorphism is poorly constrained between $770 \mathrm{Ma}$ and $702 \mathrm{Ma}$ but is compatible with the $714 \mathrm{Ma}$ and $711 \mathrm{Ma}$ possible metamorphic ages in the Bailateb Group.

The Keraf suture zone is structurally complicated. It trends N-S, discordant to the NE-SW-trending 780-760 Ma Nakasib suture [107] and the E-W-trending 730-709 Ma Allaqi-Sol Hamed suture [42] (Fig. 10). N-trending upright folds dominate the northern part, whereas $\mathrm{N}$ - and $\mathrm{NNW}$ trending sinistral strike-slip faults characterize the southern part. Sinistral movement along N- and NNW-shear zones within the suture zone occurred $\sim 580 \mathrm{Ma}$ as dated by ${ }^{40} \mathrm{Ar} /{ }^{39} \mathrm{Ar}$ ages on biotite and hornblendes separated from deformed granite [101]. Creation of the suture zone is inferred to be the result of sinistral transpression associated with early NW-SE oblique collision between East and West Gondwana at $\sim 650-600 \mathrm{Ma}$ and terminal collision of the ANS and the Saharan Metacraton at $580 \mathrm{Ma}$ [101].

No exposures of pre-Neoproterozoic crust are known along the putative western margin of the ANS north of the Bayuda Desert and the precise location of the margin is consequently speculative. It is generally accepted, however, that the accretionary contact between the ANS and Saharan Metacraton trends in a northerly direction west of the Nile [108] consistent with the geochronologic and isotopic characteristics of granite plutons at Aswan [109]. The granites are conspicuously undeformed and are typical posttectonic Neoproterozoic ANS intrusions. Earlier dating obtained a U-Pb discordia emplacement age of $594 \pm 4$ for the Monumental Granite [110] and a reasonably robust $\mathrm{U}-\mathrm{Pb}$ conventional zircon age of $634 \pm 4$ Ma for an orthogneiss roof pendant in granite southwest of Aswan, implying granite emplacement after $\sim 634 \mathrm{Ma}$ [81]. Recent ID-TIMS dating suggests that the post-tectonic granites at Aswan are actually somewhat younger, with Ediacaran crystallization ages of $606 \pm 2$ and 606-1 Ma [109]. The granites contain no inherited zircon. They also have values of $\varepsilon_{\mathrm{Nd}}=+1.4$ and +1.1 , which are low compared with typical $\varepsilon_{\mathrm{Nd}}$ values for ANS granites [23], suggesting unusual conditions of magma 
generation. The granites are markedly different from late Neoproterozoic intrusions at Gebel el Asr and Bir' Safsaf, which have strongly negative values $(-14.5,-6.1)$ and represent reworked crust of the Saharan Metacraton [111] (Fig. 10C; Table 1, samples 23-25). A roof pendant of tonalite gneiss in post-tectonic granite at Aswan yields a IDTIMS discordia age of $638 \pm 2 \mathrm{Ma}$ [109] with one inherited grain of $\sim 730 \mathrm{Ma}$. The $\mathrm{Nd}$ isotopic data, zircon ages, and absence of pre-Neoproterozoic inherited grains are evidence that the gneiss and granites do not contain components of reworked Saharan Metacraton and imply that at the time of magma generation, the closest tract of continental crust was some distance to the west. On the basis of these ages [109], it is proposed that the Aswan plutonic rocks represent an Ediacaran magmatic arc at the western margin of the Arabian Nubian Shield but some distance from the Saharan Metacraton. Geochemically, the granites are A-type with shoshonitic affinity, an exceptional characteristic for ANS granite, which is explained [109] as the possible result of magmas containing components from an enriched subduction-modified mantle wedge. The enriched mantle wedge may have developed in response to eastward subduction of the Mozambique Ocean. According to this model, arc activity occurred $\sim 630 \mathrm{Ma}$ above a subducting oceanic slab east of the passive margin of the Saharan Metacraton, making the arc broadly similar in age to the Al Amar arc [112] at the far eastern edge of the ANS in Saudi Arabia. Subsequent accretion of the arc with the Saharan Metacraton possibly engendered slab break off and provided the tectonothermal conditions for post-collision melting of the subduction-modified mantle wedge.

\section{A Putative Margin in Sinai}

Recent research at the northern limit of the exposed ANS in Sinai is an example of $\mathrm{U}-\mathrm{Pb}$ zircon dating and neodymium, oxygen, strontium, lead, and hafnium isotopic analyses that provide evidence for a new geologic discovery - the possible existence of a concealed tract of pre-ANS crust forming a margin of the ANS in northern Sinai (Figs. 1, 2). Investigations here are rapidly developing, on two fronts. Zircon $\mathrm{U}-\mathrm{Pb}$ dating indicates that volcanic arc rocks in parts of Sinai are older than previously thought and dating and isotopic analyses indicate that some detrital and xenocrystic zircon grains were sourced from old continental crust. The first evidence that older crust may be present came from the discovery of two pre-Neoproterozoic detrital zircons in pelite in the Sa'al Metamorphic Complex at the northern limit of exposed ANS in Sinai. They yielded U-Pb concordia ages of $1110 \pm 8 \mathrm{Ma}$ and $1029 \pm 7 \mathrm{Ma}$ indicating that material in the pelite was sourced from Kibaran-age crust [58]. The Sa'al Metamorphic Complex is one of four metasedimentary, metavolcanic, and gneissic assemblages that developed early in the geologic history of the northern ANS. Until recently, the Sa'al Metamorphic Complex was believed to be Cryogenian, with an age of between 820-740 Ma, but new $\mathrm{U}-\mathrm{Pb}$ zircon age data suggest that it is latest Mesoproterozoic $(\sim 1.1-1.0 \mathrm{Ga})$ [113]. The euhedral to slightly rounded shape of the inherited zircon grains implies that the grains underwent a relatively short transport and that a Kibaran-age source is close by.
Further evidence for pre-Neoproterozoic crust in the area derives from high $\delta{ }^{18} \mathrm{O}$ values $(6.1-9.4 \%$ ) obtained from cores and rims of detrital zircon grains of magmatic origin recovered from pelite in the Sa'al Metamorphic Complex [58]. The values plot above the typical mantle range for zircon and suggest that supracrustal recycling was involved in the formation of the Kibaran-age crust that was the source of the detrital grains [58]. A $\varepsilon_{\mathrm{Nd}}(t=1.0 \mathrm{Ga})$ value of +2 for the Sa'al schist is significantly lower than typical neodymium values for metamorphic rocks elsewhere in the region and suggests that the complex was derived from different sources than most of the northern ANS crust [73].

Other evidence for the existence of Kibaran-age crust in the vicinity of Sinai comes from LA-ICP-MS dating of detrital zircon grains in the late Ediacaran Elat Conglomerate ( 590-620 Ma) (Fig. 8A), $150 \mathrm{~km} \mathrm{NE}$ of the Sa'al complex [63]. As discussed above, the ages of the detrital zircon grains cluster between 880-760 Ma and 660-580 Ma with peaks at $\sim 795 \mathrm{Ma}$ and $\sim 615 \mathrm{Ma}$. But the grains also yield ${ }^{207} \mathrm{~Pb} /{ }^{206} \mathrm{~Pb}$ concordant ages of $2.5,2.1,1.97$, and $1.42 \mathrm{Ga}$, and an early Neoproterozoic Tonian tail between 1000 and $900 \mathrm{Ma}$. The source of the 880-760 Ma and 660-580 Ma grains is readily identified in Tonian-Cryogenian arc assemblages and Cryogenian-Ediacaran plutonic complexes well known in the ANS. The pre-Neoproterozoic grains are further evidence that Kibaran-age crust is nearby. Most grains have positive $\varepsilon_{\mathrm{Hf}}(t)$ values compatible with juvenile sources, but some of the pre-Neoproterozoic zircon grains have negative $\varepsilon_{\mathrm{Hf}}(t)$ values suggesting contamination of the arc magma by zircons originally crystallized by an even older crustal component.

Variations in $\delta{ }^{18} \mathrm{O}$ values for zircon grains in plutonic rocks in Sinai point to a similar conclusion. Oxygen isotope analyses have been carried out on both multigrain and single grain samples from post-collisional calc-alkaline $(\sim 635-590$ $\mathrm{Ma})$ and alkaline ( $608-580 \mathrm{Ma})$ granitic plutons as well as from the Elat Conglomerate [58, 73]. The zircon samples have average $\delta{ }^{18} \mathrm{O}(\mathrm{Zrn})$ values (5.7-5.8\%o) indicating a dominance of mantle-like $\delta{ }^{18} \mathrm{O}$ sources. But some samples from northwestern Sinai have higher values (6.9-8.2\%o) suggesting assimilation of supracrustal material during magma formation. When combined with $\mathrm{Nd}$ and $\mathrm{Hf}$ data, a geographic zoning is revealed across Sinai. An area in the southeast has relatively high positive $\varepsilon_{\mathrm{Nd}}$ values $(+4.5$ to +6$)$; low initial $\mathrm{Sr}$ ratios $(0.7020-0.7035)$; relatively high $\varepsilon_{\mathrm{Hf}}$ values (8-10); and low $\delta{ }^{18} \mathrm{O}(\mathrm{Zrn})$ values (4.5-5.9\%o). In the northwest, rocks have low $\varepsilon_{\mathrm{Nd}}$ values $(+1$ to +3$)$; some high initial $\mathrm{Sr}$ ratios $(0.7041-0.7125)$; low $\varepsilon_{\mathrm{Hf}}$ values $(5-9)$; and high $\delta{ }^{18} \mathrm{O}(\mathrm{Zrn})$ values $(6-8 \%)$. These results suggest the formation of two magmatic reservoirs in the ANS crust in Sinai - one juvenile in the southeast and one more contaminated by involvement of pre-Neoproterozoic continental material in the northwest.

Other indications of pre-Neoproterozoic crust are given by the ages of xenocrysts reported from an early Cryogenian pluton in central Sinai, the Moneiga quartz diorite $(844 \pm 4$ $\mathrm{Ma}, \mathrm{U}-\mathrm{Pb}$ ion-microprobe crystallization age), and from an Ediacaran post-tectonic syenogranite $\left(594 \pm 8 \mathrm{Ma}:{ }^{207} \mathrm{~Pb} /{ }^{206} \mathrm{~Pb}\right.$ zircon age) in eastern Sinai. The Moneiga quartz diorite has initial $\mathrm{Sr}$ and $\mathrm{Nd}$ isotope values $\left({ }^{86} \mathrm{Sr} /{ }^{87} \mathrm{Sr}_{844 \mathrm{Ma}}=\right.$ $\left.0.703187 \pm 0.000034 ; \varepsilon_{\mathrm{Nd}}(844 \mathrm{Ma})=+3.5 \pm 0.5\right)$ only slightly 
less primitive than those of rocks with a similar age elsewhere in the ANS [114]. However the quartz diorite also contains Kibaran-age zircon cores dating $1045 \pm 13$ Ma, $1046 \pm 13 \mathrm{Ma}$, and $1025 \pm 13 \mathrm{Ma}$. These are about 200 million years older than the age of magma crystallization. Furthermore, the major and trace-element compositions of the quartz diorite are more enriched in the most incompatible elements than would be expected for purely juvenile arc magma. In addition, the pluton has low $\mathrm{Ba} / \mathrm{La}$ and $\mathrm{Cs} / \mathrm{Sc}$ and high $\mathrm{Zr} / \mathrm{Yb}$, features suggesting the presence of a crustal component [114]. Moreover, the Moneiga quartz diorite has a $\mathrm{Nd}$ model age of $1.06 \mathrm{Ga}$ similar to the U-Pb zircon core ages, which leads [114] to the conclusion that the source of Moneiga magma mostly consisted of melted $\sim 1.05 \mathrm{Ga}$ crustal material. The Ediacaran post-tectonic pluton in the east is $594 \pm 8 \mathrm{Ma}\left({ }^{207} \mathrm{~Pb} /{ }^{206} \mathrm{~Pb}\right.$ zircon age) syenogranite and contains one xenocryst with a concordant Paleoproterozoic age of $1789 \pm 56 \mathrm{Ma}$ [48].

Overall, inheritance is not common in plutonic rocks in Sinai, as shown by the lack of pre-Neoproterozoic ages in other dating programs in the area (e.g., [38]). Nonetheless, the data do support a model of basement heterogeneity and are permissive of the presence of an enigmatic tract of preANS crust at, or farther north than, the northern exposure of the ANS in Sinai. The exact location and extent of such crust, however, is elusive.

\section{Eastern Margin of ANS}

The eastern margin of the ANS is less well defined than the western because there is limited outcrop evidence of a contact between juvenile Neoproterozoic rocks and older crust and relatively little available isotopic data. In the far south, the eastern margin is approximately defined by the Mutito-Buna shear zone [96], which separates juvenile Neoproterozoic volcanosedimentary rocks intercalated with high-grade gneisses from high-grade gneisses and migmatites assigned to the putative Azania block (Figs. 1, 2). The volcanosedimentary rocks yield U-Pb zircon SIMS (SHRIMP), LA-ICP-MS, and ${ }^{207} \mathrm{~Pb} /{ }^{206} \mathrm{~Pb}$ evaporation ages defining four principal magmatic episodes: 840-890 Ma (late Tonianearly Cryogenian), 790-700 Ma (middle Cryogenian), 660 Ma (late Cryogenian), and 630-500 Ma (Ediacaran to Cambrian) $[40,51,53]$. Mafic rocks predominate, consisting of subalkaline, low-K, low-Ti tholeiitic basalts, boninites, and high-Ti, high-K calc-alkaline basalts. They have the chemical signature of rocks developed above subduction zones [53] and are characterized by $1.2-0.96 \mathrm{Ga} \mathrm{Nd}$ model ages and positive $\varepsilon$ Nd $(700$ Ma) values $(+2.6-+3.2)$ $[40,51,53]$. The rocks are undoubtedly Neoproterozoic juvenile rocks similar to those in other parts of the ANS.

Azania, to which the high-grade rocks east of the MutitoBuna shear zone are tentatively assigned, comprises a belt of 2.90-2.45 Ga gneisses identified by [26] as extending from central Madagascar into northern Somalia, eastern Ethiopia, and possibly Yemen. It is envisaged [26] that Azania, or at least its southern part, was adjacent to the Congo Craton in the late Paleoproterozoic-early Mesoproterozoic but separated from the craton during the Neoproterozoic because of roll-back of the Mozambique slab above a subduction zone, opening a back-arc basin between Azania and the craton. There is no robust evidence that the high-grade rocks are Archean, but Archean protoliths are inferred in the region on the basis of $\mathrm{U}-\mathrm{Pb}$ zircon SIMS dating of intrusions in the adjacent volcanosedimentary rocks [40]. Undeformed granite in the Moyale area of southern Ethiopia (Fig. 1), for example, that contains zircon with an age as young as $568 \pm 9$ $\mathrm{Ma}$, also contains Archean and Paleoproterozoic zircon yielding a three-grain mean age of $2514 \pm 18 \mathrm{Ma}(\mathrm{MSWD}=$ 0.18 ) [40]. Samples of granite gneiss, metarhyolite, and granodiorite gneiss elsewhere in the belts, however, have very low positive $(+0.6)$ or even negative $(-0.8,-1.2) \varepsilon_{\mathrm{Nd}}(700$ Ma) values suggesting only minor, if any, input from Archean material [51]. The $568 \mathrm{Ma}$ granite results are interpreted as indicating either a $\sim 2.5 \mathrm{Ga}$ igneous rock that was metamorphosed in late Neoproterozoic time or a late Neoproterozoic melt of Archean crust. Because the granite is undeformed, the preferred interpretation is that it is an Ediacaran intrusion that was generated by melting of $\sim 2.5$ Ga crust or by melting of sediments with a concentration of Archean zircon [40].

Northward, because of Cenozoic basalt cover, crystalline basement is only sparsely exposed. Exposures in eastern Ethiopia, around Harar, consist of granite gneiss and migmatite, amphibolite-facies metasedimentary rocks such as quartz-muscovite schist and andalusite-garnet schist, and lower grade phyllite and metavolcanic rocks [51]. Many of the rocks have $844-649 \mathrm{Ma}{ }^{207} \mathrm{~Pb} /{ }^{206} \mathrm{~Pb}$ evaporation ages and are interpreted as Neoproterozoic. However, three zircon grains from a sample of granodiorite gneiss yield a mean precursor crystallization ${ }^{207} \mathrm{~Pb} /{ }^{206} \mathrm{~Pb}$ evaporation age of $2489 \pm 0.5 \mathrm{Ma}$, several samples have Archean xenocrystic zircon $(2.9-2.3 \mathrm{Ga})$, and all samples $(\mathrm{n}=5)$ have negative $\varepsilon_{\mathrm{Nd}}(700 \mathrm{Ma})$ values $(-4.2$ to -18.3$)$. All samples also have Paleoproterozoic and Archean Nd model ages (2.88-1.62 $\mathrm{Ga}$ ), and the data are strong evidence of old crust in the region [51].

Crystalline rocks in northern Somalia include marbles, quartzite, and amphibolite of the Mora Complex interlayered with amphibolite-grade paragneiss, migmatite, felsic orthogneiss, amphibolite, and rare talc-silicate rocks of the Qabri Bahar Complex [62] (Figs. 1, 2). These rocks have Neoproterozoic emplacement and metamorphic ages but contain Paleoproterozoic and Mesoproterozoic xenocrysts. Xenocrysts from granite orthogneiss and migmatite leucosome in the Mora metasedimentary rocks yield ${ }^{207} \mathrm{~Pb} /{ }^{206} \mathrm{~Pb}$ evaporation ages of $1402 \pm 5 \mathrm{Ma}$ and $1422 \pm 5 \mathrm{Ma}$, whereas the orthogneiss and leucosome themselves have emplacement and formation ages of $718 \pm 9 \mathrm{Ma}$ and $842 \pm 4$ Ma [62]. Xenocrysts of 1.8-1.7 Ga are obtained from migmatite in the Qabri Bahar Complex that developed during a $808 \pm 6 \mathrm{Ma}$ thermal event. On the basis of these results, it is proposed that the basement in northern Somalia comprises 1.8-1.4 Ga pre-Neoproterozoic crust reworked by $\sim 840-720 \mathrm{Ma}$ igneous and metamorphic events [62] and the basement is tentatively interpreted as part of Azania [26] (Figs. 1, 2).

It is significant however, that the so-called Azania block in northern Somalia appears to have a finite east-west width and juvenile Neoproterozoic rocks composed of pillow lava, microgabbro, and greenschist-facies metasedimentary rock crop out on the eastern side of the block. These Neoproterozoic rocks, the Mait Complex (Figs. 1, 2), may 
represent a continuation of the ANS east of Azania, and are possibly equivalent to to the Al Mukalla terrane in Yemen (Fig. 2) [61]. This is the reason why Azania is modeled as a narrow strip of Archean crust [26] even though it has a strike length of more than $3000 \mathrm{~km}$. Neoproterozoic rocks are identified farther east in the island of Socotra, but here the rocks are interpreted as having originated in a Cryogenian active margin close to India [115] rather than being part of the ANS. If this interpretation is correct, it implies that the true eastern margin of the ANS is located somewhere between northern Somalia and Socotra. Socotra Island is south of the Gulf of Aden spreading center and forms the extreme eastern tip of the African Plate but, during the Neoproterozoic, may have been an Andean-type arc and back-arc at the margin of India, tectonically distinct from the juvenile arcs of the ANS developing in the Mozambique Ocean [115]. The crystalline basement of the island represents three Cryogenian events over a $\sim 80$ million year period comprising: (1) high temperature ductile deformation and metamorphism in a possible compressive or transpressive regime; (2) later sheeted mafic to intermediate dikes, gabbro laccoliths, mafic lavas possibly emplaced in a back arc; and (3) final emplacement of 840-780 Ma granite.

In Yemen, an ANS-Azania boundary in probably defined by arc-continent sutures along the Abas and Al Mahfid terranes (Fig. 2) [61]. These terranes consist of orthogneisses, migmatite, and metamorphosed supracrustal rocks, separated by shear zones from supracrustal rocks of the Al Bayda and Al Mukalla terranes. The Al Bayda and Al Mukalla terranes contain greenschist-grade felsic and mafic volcanic rock and granodiorite and granite intrusions and are interpreted as juvenile Neoproterozoic island arcs sutured to older crust of the Abas and Al Mahfid terranes. The gneissic terranes have present-day $\varepsilon_{\mathrm{Nd}}$ values of -10.6 to -39.8 and Archean-Paleoproterozoic Nd model ages (3.03-1.7 Ga), and the Al Mahfid terrane yields 2.94-2.55 Ga U-Pb SIMS (SHRIMP) zircon ages, indicating the presence of Archean continental crust, albeit with extensive Neoproterozoic reworking $[60,61,116]$. The region is interpreted as an alternation of pre-Neoproterozoic gneissic domains and Neoproterozoic island-arc domains that coalesced to form an arc-gneiss collage contemporaneous with accretionary events in the main part of the ANS [61,116]. As in Somalia, Neoproterozoic arc rocks (Mukalla terrane) continue east of the Azania gneisses, indicating that Azania, both in Somalia and Arabia, has a limited east-west width and possibly forms a ribbon-like continental block within ANS juvenile crust. Basement rocks farther east are concealed by Phanerozoic cover, but reappear in Oman. The Oman basement has Cryogenian crystallization and metamorphic ages, and in this respect is similar to ANS crust, but appears to have a different geologic history [66] and may have originated in proximity to the India block as is inferred for the rocks on Socotra.

\section{Is there an ANS Margin in Central Arabia?}

The presence of an eastern ANS margin in Saudi Arabia is currently unknown and there is debate about where it may conceivably be located. Paleoproterozoic crust crops out in the Khida terrane, a crustal block that indents juvenile ANS rocks in the eastern part of the Arabian Shield (Figs. 1, 2, 11). But juvenile ANS rocks continue east of the Khida terrane to the farthest exposed edge of the shield where Neoproterozoic rocks are unconformably overlain by Phanerozoic strata. Farther east, Precambrian basement is concealed by more than 10 kilometers of Phanerozoic sedimentary rocks and does not crop out again until small exposures in Oman (Figs. 1, 2). Although geophysical data demonstrate that crystalline basement is indeed present beneath the Phanerozoic, determination of the provenance of the basement rocks will require examination of samples of Precambrian rocks intersected in holes drilled for oil exploration on the Arabian Platform. Consequently, no firm evidence currently exists to control speculation about an eastern margin of ANS-type juvenile Neoproterozoic rocks in Saudi Arabia.

The Khida terrane (Fig. 11) is a triangular area at the eastern margin of the exposed shield. It was first suggested by the discovery of high ${ }^{208} \mathrm{~Pb} /{ }^{204} \mathrm{~Pb}$ and ${ }^{207} \mathrm{~Pb} /{ }^{204} \mathrm{~Pb}$ in feldspar extracted from post-tectonic Cryogenian and Ediacaran granites in the region. This finding suggested that the host rocks contain a large component of older continental lead in contrast to rocks elsewhere in the Arabian Shield that have lead of oceanic character. These older leads were initially referred to as Type II [77], but are now referred to as Type III [117]. Juvenile oceanic lead, concentrated in the western arc terranes of the ANS (Fig. 2), is referred to as Type I. An intermediate Type II lead with mixed oceanic and continental characteristics is found in rocks east of and north of the Khida terrane [5]. Type III lead in the Khida area is interpreted as evidence that pre-Neoproterozoic continental material existed in the region and is the basis for the identification of a crustal block referred to as the Khida terrane [118]. In the mid 1980s, a Paleoproterozoic U-Pb age was obtained from granodiorite at Jabal Khida at the extreme edge of the block (Sample Z-103; [119]) and garnetsillimanite gneiss suggested another Paleoproterozoic age to the west [120]. The Jabal Khida granodiorite was interpreted as either $\mathrm{a} \sim 1.7 \mathrm{Ga}$ intrusion or a Neoproterozoic intrusion with a Paleoproterozoic source. Although it is now known that this particular sample has, in fact, a Neoproterozoic crystallization age of $756 \pm 6 \mathrm{Ma}$ [59], recent $\mathrm{U}-\mathrm{Pb}$ dating reveals felsic gneiss (Libab gneiss) containing zircon grains with 2.4-2.1 Ga cores and 1.9-1.75 Ga rims and a granite (Mujayil suite) dated at $1.6 \mathrm{Ga}([59,118]$ elsewhere in the area. The U-Pb ages and compatible $\mathrm{Nd}$ model ages of 2.4$1.6 \mathrm{Ga}$ (Fig. 11C), establish that Paleoproterozoic rocks crop out at the far eastern edge of the shield [59, 118]. The outcrops are small in area and most other exposures in the region comprise early Cryogenian metasedimentary schist and gneiss, middle Cryogenian arc assemblages, and Ediacaran granite. All the rocks, however, contain Type III lead and yield Paleoproterozoic model ages, indicating that continental crust of the Khida terrane either exists at depth to the northwest or, if thoroughly reworked, has left an isotopic signature reflecting its original extent. Thorough reworking is suggested by the extent of Ediacaran granite in the terrane (Fig. 11). Granite occupies much of the surface area of the terrane and a vast granite body in the subsurface is evidenced by a conspicuous gravity low in the heart of the terrane 

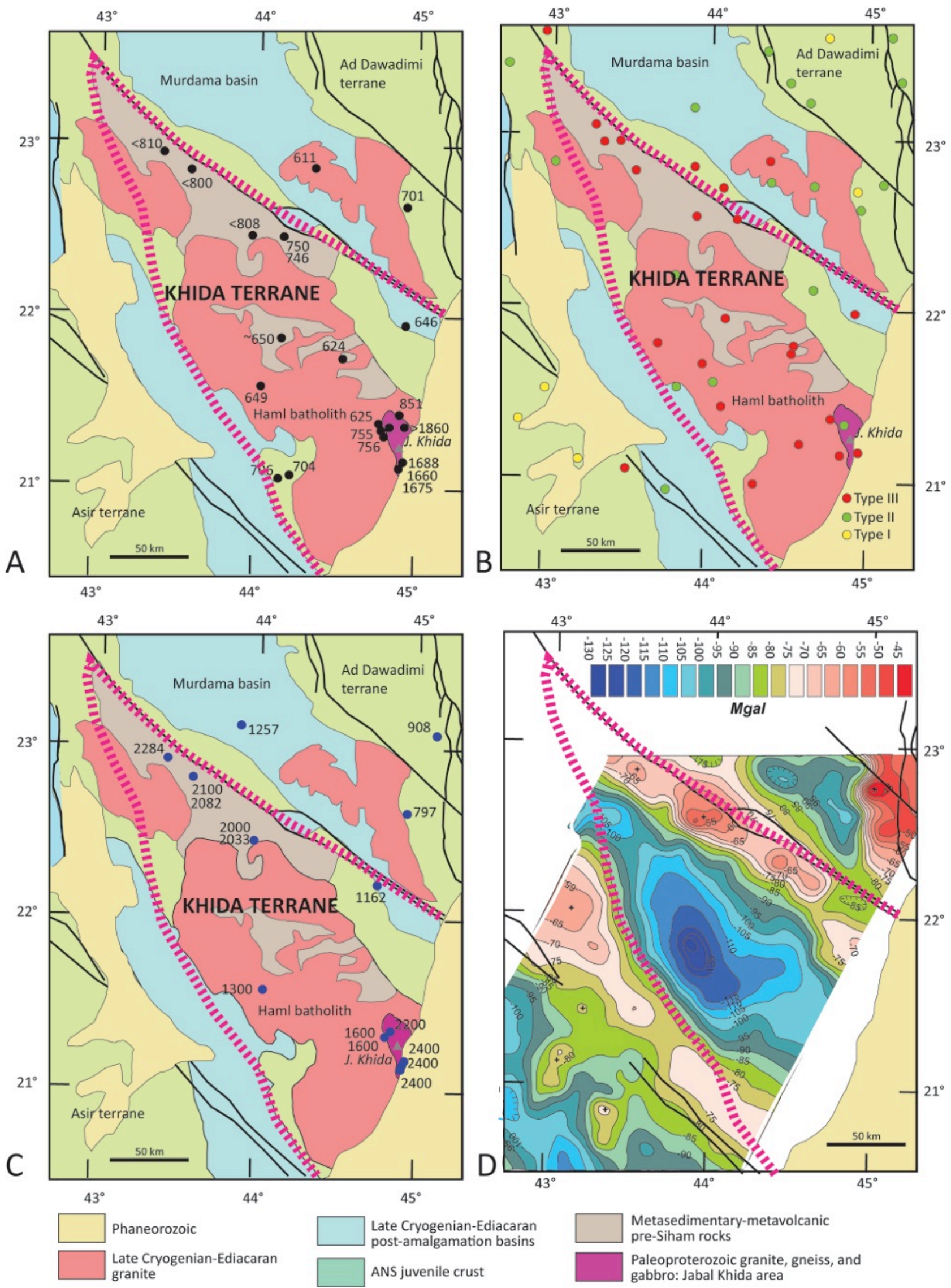

Fig. (11). Plot of U-Pb ages (A), lead types (B), neodymium model ages (C) and Bouguer gravity (D) for the eastern part of the Arabian Shield illustrating types of data that evidence Paleoproterozoic rock exposures and concealed or reworked Paleoproterozoic crust defining the Khida terrane. See text for sources of data. 
(Fig. 11D) [121]. Seismic-refraction profiling indicates that the region is underlain by a layered crust, the upper $20 \mathrm{~km}$ of which is modeled as granitic material, the lower $20 \mathrm{~km}$ as more mafic material [121]. It is likely, therefore, that most of the original Paleoproterozoic rock of the terrane has been reworked as a component of Ediacaran granite magma.

How far the Khida terrane extends beneath Phanerozoic rocks to the southeast is unknown, but magnetic anomaly maps suggest that it extends at least as far south as the Yemen border, and similarities between the Khida terrane and the Abas and Al Mahfid terranes in Yemen suggest continuity of old continental crust between central Arabia and Yemen [59-61] (Figs. 1, 2).

The rocks exposed in the Arabian Shield on either side of the Khida terrane have Neoproterozoic crystallization ages but, compared to rocks farther west, have slightly elevated ${ }^{208} \mathrm{~Pb} /{ }^{204} \mathrm{~Pb}, \delta{ }^{18} \mathrm{O}$ values, and neodymium and strontium initial ratios [5]. On this basis, particularly that of the lead data, a fundamental isotopic boundary is drawn across the shield approximately along the suture at the western edge of the Afif terrane (Fig. 2), dividing the shield into eastern and western arc terranes [5]. The data suggest that the western arc terranes were derived from depleted mantle sources, and they are referred to as oceanic. The eastern terranes were derived either from mantle contaminated by a small continental component or the asthenosphere beneath the eastern part of the shield had a composition slightly different from that in the west [5]. Apart from the Khida terrane, there is no evidence however of any intact pre-Neoproterozoic rocks exposed in, or in the crust beneath, this eastern part of the shield. The Ar Rayn terrane at the easternmost edge of the shield (Fig. 2) is composed of $>689$ to $\sim 625 \mathrm{Ma}$ volcanosedimentary rocks and arc-related 689-616 Ma trondhjemite, tonalite, and granodiorite intruded by $607-583$ Ma syn- to post-tectonic alkali granite [112]. The rocks make up a late Cryogenian-Ediacaran arc system, the youngest arc known in the Arabian Shield, and similar in age to the arc proposed [109] at the opposite western edge of the ANS at Aswan. The arc rocks of the Ar Rayn terrane have geologic, structural, and metallogenic characteristics analogous to an Andean continental-margin arc [112] and it has been suggested that a continental block lies beneath the Arabian Platform east of the exposed shield coincident with the major $\mathrm{N}-\mathrm{S}$ magnetic boundary observed in this part of the Arabian Plate [27]. This boundary is envisaged [122] as the leading, westward edge (a suture?) of a crustal block underlying much of central Arabia, with the Ar Rayn terrane at its western margin. It is alternatively proposed [65] that the basement beneath the Arabian Platform comprises other ANS-type arcs and that any ANS eastern margin lies some distance east of the eastern edge of the exposed shield. It is notable that all rocks analyzed for neodymium isotopes in the area yield age-adjusted positive $\varepsilon_{\mathrm{Nd}}$ values. These range from +3.1 to +6.5 for three plutonic rock samples in the Ar Rayn terrane and +1.6 to +6.9 for four plutonic rock samples in the Ad Dawadimi terrane immediately to the west suggesting that their magmas were derived from depleted sources with minimal or no crustal input [75]. On this basis, it is unlikely that continental crust is present anywhere close to the eastern exposed limit of the ANS in central Saudi Arabia and further assessment of the proposal by [65] is warranted.

\section{DISCUSSION}

This review of current geochronologic and isotopic datasets illustrates the critical contribution that these types of data make to robust, meaningful understanding of the tectonic setting and extent of the shield. Without reliable geochronology there is no accurate lithostratigraphy or temporal sequencing of deformation and metamorphic events; without isotopic data there is little insight into magma genesis or crustal recycling.

Apart from the well-documented and easily explained Paleoproterozoic to Neoproterozoic origins of the Khida terrane and terranes in Yemen, existing data consistently and elegantly demonstrate that the Neoproterozoic rocks of the shield are largely juvenile. From oldest $(\sim 850 \mathrm{Ma})$ to youngest $(\sim 680-610 \mathrm{Ma})$, arc assemblages as well as syn-, late- and post-tectonic granitic plutons yield age-adjusted positive $\varepsilon_{\mathrm{Nd}}$ values. Lithologically and geochemically the arc assemblages evince formation as intraoceanic or rare continental-margin arcs. Pre-tectonic arc-related granitoids have tholeiitic to calc-alkaline trends, plot in the fields of volcanic-arc and within plate granites on $\mathrm{Rb} / \mathrm{Y}+\mathrm{Nb}$ and $\mathrm{Hf}-$ $\mathrm{Rb}$-Ta discrimination diagrams, and commonly have adakitic affinities compatible with an oceanic setting (e.g., [80]); mafic lavas range from subalkaline, low-K, low-Ti tholeiite basalt to high-K, high-Ti calc-alkaline basalt, or are locally boninitic. Ophiolites in the ANS, apart from the Gebel Gerf complex that has N-MORB chemistry [141], typically formed in forearc settings and have strongly positive $\varepsilon_{\mathrm{Nd}}$ $(+5.0$ to +7.7$)$ [124]. Late- to post-tectonic granitoids document magmatic transitions from calc-alkaline I-type to within-plate alkaline A-type settings but again have positive $\varepsilon_{\mathrm{Nd}}$ values typical of those expected for contemporary Neoproterozoic asthenospheric mantle, not continental crust [36].

Widespread acceptance of the juvenile character of the ANS has come about in the past decade, although consensus is not universal and the topic is still debated. A particular cause for this debate concerns the geologic significance of gneiss domes or structural highs in the Eastern Desert of Egypt. One view is that the gneisses are a window into or a melt derived from an underlying pre-Neoproterozoic infracrust - an extension of the Saharan Metacraton beneath the ANS. The other view is that the gneiss protoliths are juvenile Neoproterozoic melts. For many years, the former view prevailed, based on the relatively high metamorphic grade of the gneiss domes and their structural relationship to typical arc rocks of the shield, occurring in the cores of structural highs separated from supracrustal arc rocks by high-strain zones, shears, and thrusts. However, the protoliths of the Eastern Desert gneiss domes consistently yield Neoproterozoic U-Pb zircon ages and the rocks have neodymium, strontium, and hafnium isotope characteristics of a juvenile origin. The data strongly indicate that they derived from the lower crust of a mid-Neoproterozoic volcanic arc or a mantle-derived mafic melt [41], not from older crust, and the gneisses are most reasonably interpreted as syn-tectonic intrusions $[43,50]$. An analogous debate occurred in the Arabian Shield, where gneisses in the Khamis Mushayt area of the southern Arabian Shield were mapped in the $1970 \mathrm{~s}$ as basement of possible Mesoproterozoic age, stratigraphically beneath younger arc 
assemblages [123]. U-Pb dating in the 1980s reversed this interpretation however, and established that the gneisses were Cryogenian and represented syn-tectonic plutons intruded into arc assemblages during the Nabitah orogeny (680-840 Ma) ([125, 117]. In the Eastern Desert, the present body of geochronologic and isotopic does not support any view that older crust is present and, instead, confirms the long held interpretation that the ANS arcs and granitic rocks are juvenile [126].

A caveat to the conclusion that no older basement is present in the ANS other than the Khida terrane may be argued by some because of the discovery of preNeoproterozoic xenocrystic and detrital zircons in Neoproterozoic rocks in parts of the shield. These inherited zircons undoubtedly require pre-Neoproterozoic sources and warrant further investigation. As described above, preNeoproterozoic xenocrysts are known in granitic plutons in the Arabian Shield and in mafic plutons and volcanic rocks in both Arabian and Nubian Shields. They indicate input from old continental sources, while cobbles and boulders of $\sim 1.8$ and $\sim 2.5 \mathrm{Ga}$ rock and inherited zircon grains in $\sim 750$ Atud diamictite in the Eastern Desert are direct evidence of nearby pre-Neoproterozoic crust [56]. The problem is that magmatic rocks that contain xenocrysts also have $\mathrm{Nd}$, Hf, and $\mathrm{O}$ isotopic characteristics that mostly indicate derivation from depleted (asthenospheric) mantle or lower crust composed of arc material, and evince formation in intraoceanic juvenile settings $[50,57,80]$. The questions then are where did the xenocrystic zircons come from and how did they become entrained in Neoproterozoic melts? To start giving an answer it should be noted that "... the presence of abundant pre-Neoproterozoic zircons only indicates the presence of older zircons, not the presence of extensive tracts of older crust" [50]. As is well known, zircon is highly refractory and resistant to change during melting, metamorphism, deformation, or erosion: it can survive extensive melting and be carried back to the surface in magmas. Paleoproterozoic cobbles, boulders, and detrital grains in Atud diamictite, if truly glaciogenic, merely indicate that glaciers moved over a pre-Neoproterozoic landscape and plucked up debris that was ultimately dropped in the Mozambique Ocean. With regard to xenocrysts in magmatic rocks, there is no evidence of wholesale melting of pre-Neoproterozoic crust during Neoproterozoic ANS magmatism [31, 49] other than for the creation of granitic magmas in the Khida terrane, possibly southern Ethiopia, and parts of Sinai. Tectonic models that envisage extensive continental crust beneath the ANS are therefore unwarranted. Another explanation could be that zircons from far distant crustal sources were introduced as sediment into the Neoproterozoic marine basin in which ANS crust developed and that subsequent melts rising through the sediments incorporated detrital zircons by assimilation [80]. An analogy is the situation in Indonesia where sediment currently being subducted beneath Sumatra was transported into the Java trench from the Bengal Fan by longitudinal currents along the trench, and clastic material on the Bengal Fan, in turn, derives from the eroding Himalaya Mountains [132]. However, given the euhedral form of many ANS xenocrystic zircons, showing no or little evidence of erosional rounding, this explanation is not fully convincing for the ANS samples. Another possibility [31], is that the ancient zircons were present in the mantle where ANS juvenile melts were generated and were entrained with juvenile melts rising to the surface. The preservation of zircon xenocrysts in the mantle is the explanation, for example, for the presence of inherited ancient zircons in mid-Atlantic ridge MORB-type gabbros [127, 128]. A similar origin may account for inherited zircons found in ophiolites (fossil oceanic crust) (e.g. [129]), including the Neoproterozoic Thurwah ophiolite in the Arabian Shield $[130,131]$. Another factor is the orogenic climax that occurred between 1.2 and $1.1 \mathrm{Ga}, \sim 250 \mathrm{~m} . \mathrm{y}$. prior to the beginning of ANS magmatism. During this period, the Earth's crust and mantle was affected by an unprecedented amount of subduction-related recycling associated with assembly of Rodinia [83]. The resulting Grenville-age orogens spanned 25 percent of the globe or a distance of $\sim 20,000 \mathrm{~km}$ along strike and as wide as $800 \mathrm{~km}$. In either scenario, it is conceivable that sediment eroded from Mesoproterozoic and older continental was carried down subducting slabs deep into the mantle, thereby contaminating the mantle with xenocrystic zircon grains that eventually reappeared in Neoproterozoic melts. The apparent temporal control on inheritance whereby older mafic magmas contain more xenocrysts proportionately than younger late- to posttectonic felsic magmas is possibly explained by the timing of ANS arc complexes and the transition to within-plate magmatism. The volume of ANS arc complexes implies the extraction of large amounts of magma from the mantle and it is possible that by the end of the Cryogenian the mantle wedges above subduction zones in the Mozambique Ocean could have been virtually purged of inherited zircon. At this stage, however, the question of how pre-Neoproterozoic zircons got into Neoproterozoic mantle remains unresolved and a topic of debate.

The ANS represents a major growth of Neoproterozoic crust, and together with other terranes along the northern border of Amazonia and West Africa amounts to an addition of 50 percent of all juvenile crust on Earth produced between $750 \mathrm{Ma}$ and $550 \mathrm{Ma}$ [133]. The rate at which ANS crust developed has been an important consideration in discussions about the growth rate of continental crust. A preferred rate allows for rapid creation of 60 percent of total global crust by $2.5 \mathrm{Ga}$, followed by moderate early Proterozoic growth to a total of 80 percent by $1.7 \mathrm{Ga}$ and modest growth of the remaining 20 percent to the present [134]. Within this framework, the estimated volume and age of the ANS appears for some to be problematic. It has been estimated [135] that the ANS represents a Neoproterozoic crustal addition rate of $400 \mathrm{~km}^{3} \mathrm{~km}^{-1} \mathrm{Ma}^{-1}$, requiring the addition of 10 or more arcs of $2500 \mathrm{~km}$ length operating simultaneously at an average rate of $30 \mathrm{~km}^{3} \mathrm{~km}^{-1} \mathrm{Ma}^{-1}$. However, this was deemed by the authors [135] to be problematic because the rate far exceeds the Phanerozoic rate and caused them to conclude that the island-arc model for creation of the ANS was doubtful. A different study [136] likewise concluded that "late Precambrian growth rates for continental crust in the Arabian-Nubian craton are implausibly high for simple accretion models." These concerns may be exaggerated, however, because of assumptions made by the authors about the size of the ANS. For the purpose of estimating the crustal growth rate, an ANS "arc-province" model was adopted [135] that extended 
from the Nile, across the entire Arabian Plate to the contact with the Eurasian Plate in the Zagros Mountains, but this width may be excessive. As reviewed here, the eastern ANS margin, though currently unknown, is possibly in the basement beneath central Arabia rather than farther east in the Zagros Mountains. Features that suggest an eastward limitation of the ANS include arguments that a crustal block different in character to the Arabian Shield is present beneath eastern Arabia [27] and that the Neoproterozoic crust in Oman has a different history than the typical ANS [66]. It is envisaged that ANS-type arcs continue some distance beneath the Phanerozoic of the Arabian Platform, but that the Neoproterozoic-early Cambrian Huqf Supergroup was deposited on the leading edge of Neoproterozoic India [65], compatible with the interpretation [115] of juvenile Neoproterozoic rocks in Socotra as a Cryogenian active margin at the edge of India. These interpretations suggest that ANS does not, in fact, extend to the Zagros Mountains but ends some hundreds of kilometers west of the mountains. Another factor unknown for estimates of the volume of continental crust represented by the ANS in the 1980s, is the presence of a significant volume of Archean and Paleoproterozoic crust intercalated with Neoproterozoic rocks, represented by the Khida terrane, terranes in Yemen, and the pre-Neoproterozoic gneisses of Azania. The western boundary of the ANS with the Saharan Metacraton is reasonably well mapped. A boundary, long suspected in the vicinity of the Nile, is accurately defined by current geochronologic and isotopic data and geologic mapping in the Bayuda Desert, the Nuba Mountains and Kenya and Tanzania. A northwestern boundary is suggested in Sinai. Although the Saharan Metacraton itself may contain some Neoproterozoic crust, such confident delineation of the principal western limit of ANS crust is important for refining estimates of Neoproterozoic crustal growth rates, helps constrain tectonic modeling of ANS evolution, and critically controls modeling of the timing and structure of terminal ANS/Saharan Metacraton collision and accretion of Gondwana.

\section{CONFLICT OF INTEREST}

The author declares to have no conflict of interest.

\section{ACKNOWLEDGEMENTS}

The author is grateful to the Saudi Geological Survey for providing the opportunity to work in the Arabian Shield over three decades, gaining knowledge of its structure, stratigraphy, and tectonic development. The author also wishes to thank two reviewers for the Open Geology Journal, Alfred Kröner and one anonymous, whose careful reading of the manuscript and abundant comments have significantly improved the text.

\section{REFERENCES}

[1] Stern RJ. Arc assembly and continental collision in the Neoproterozoic East African Orogen. Annu Rev Earth Planet Sci 1994; 22: 319-51.

[2] Johnson PR, Andresen A, Collins AS, et al. Late CryogenianEdiacaran history of the Arabian-Nubian Shield: a review of deposition, plutonic, structural, and tectonic events in the closing stages of the northern East African Orogen. J Afr Earth Sci 2011; 61: $167-232$.

[3] Fritz H, Abdelsalam M, Ali KA, et al. Orogen styles in the East African Orogen: a review of the Neoproterozoic to Cambrian tectonic evolution. J Afr Earth Sci 2013; 86: 65-106.

[4] Berhe SM. Ophiolites in Northeast and East Africa: implications for Proterozoic crustal growth. J Geol Soc Lond 1990; 147: 41-57.

[5] Stoeser DB, Frost CD. Nd, Pb, Sr, and O isotopic charcterization of Saudi Arabian Shield terranes. Chem Geol 2006; 226: 163-88.

[6] Klemm D, Klemm R, Murr A. Gold of the Pharaohs - 6000 years of gold mining in Egypt and Nubia. J Afri Earth Sci 2001; 33: 643659.

[7] Lefèvre MT. Letter addressee á M. Cordier. Bull Soc Géol France 1839; 10: $144-48$.

[8] Stanely AP. Sinai and Palestine in connection with their history. London: John Murray 1875.

[9] Doughty CM. Travels in Arabian Deserta. Cambridge: Cambridge University Press 1888.

[10] Ritter C. Vergleichende Erdkunde der Sinai Halbinse, von Palästina und Syrien. Berlin: G. Reimer 1848-55.

[11] Auler P. Die Hedschasbahn II Tiel: Ma'an bis el-Ula. Petermanns Geog Mitt Ergänzungsheft 1908; 161: 1-66.

[12] Blanckenhorn M. Syrien, Arabien und Mesopotamien: Handbuch der regionalen Geologie. Heidelberg: C. Winter 1914.

[13] Hume WF. Geology of Egypt VII: The fundamental pre-Cambrian rocks of Egypt and the Sudan, their distribution, age, and character. Part 1 The metamorphic rocks. Cairo: Government Press 1934.

[14] Said R. The geology of Egypt. Amsterdam-New York: Elsevier 1962.

[15] Powers RW, Ramirez LF, Redmond CD, et al. Geology of the Arabian Peninsula-Sedimentary geology of Saudi Arabia. US Geol Surv Prof. Pap. 1966; 560-D:1-147.

[16] Bender F. Geology of Jordan. Berlin: Gebruuder Borntraeger 1974.

[17] Delfour J. Comparative study of mineralization in the Nubian and Arabian Shield. Jiddah: Directorate General of Mineral Resources 1976.

[18] Brown GF, Schmidt DL, Huffman AC. Geology of the Arabian Peninsula: shield area of western Saudi Arabia. US Geol Surv Prof Pap 1989; 560-A: 1-188.

[19] Shimron AE. Proterozoic island arc volcanism and sedimentation in Sinai. Precambrian Res 1980; 12: 437-58.

[20] Vail JR. Pan-African (late Precambrian) tectonic terrains and the reconstruction of the Arabian-Nubian Shield. Geology 1985; 13: $839-42$.

[21] Stoeser DB, Camp VE. Pan-African microplate accretion of the Arabian Shield. Geol Soc Am Bull 1985; 96: 817-26.

[22] USG-ARAMCO. Geologic map of the Arabian Peninsula. U.S. Geol. Surv. Miscellaneous Geologic Investigations Map 1963; I270: scale 1:2,000,000.

[23] Stern RJ. Crustal evolution in the East African Orogen: a neodymium isotopic perspective. J Afr Earth Sci 2002; 34: 109-17. Abdelsalam MG, Liégeois J-P, Stern RJ. The Saharan Metacraton. J Afr Earth Sci 2002; 34: 119-36.

[25] Johnson PR, Woldehaimanot B. Development of the ArabianNubian Shield: perspectives on accretion and deformation in the northern East African Orogen and the assembly of Gondwana. In: Yoshida M, Windley BF, Dasgupta S, Eds. Proterozoic East Gondwana supercontinent assembly and breakup. London: Geological Society 2003; pp. 289-325.

[26] Collins AS, Pisarevsky SA. Amalgamating eastern Gondwana: the evolution of the circum-Indian orogens. Earth-Sci Rev 2005; 71: 229-70.

[27] Stern RJ, Johnson P. Continental lithosphere of the Arabian Plate: a geologic, petrologic, and geophysical synthesis. Earth-Sci Rev 2010; 101: 26-67.

[28] GIS ARABIA http://gisarabia.brgm.fr/ [Accessed: July 24, 2013].

[29] Johnson PR, Kattan FH. The geology of the Saudi Arabian Shield. Jiddah: Saudi Geological Survey 2012.

[30] Cooper JA, Stacey JS, Stoeser DB, et al. An evaluation of the zircon method of isotopic dating in the southern Arabian craton. Contrib Min Pet 1979; 68: 429-39.

[31] Stern RJ, Ali KA, Liégeois JP, et al. Distribution and significance of pre-Neoproterozoic zircons in juvenile Neoproterozoic igneous rocks of the Arabian-Nubian Shield. Am J Sci 2010; 310: 791-811. 
[32] Johnson PR, Kattan FH. Geochronologic dataset for Precambrian rocks in the Arabian Peninsula. Jiddah: Saudi Geological Survey 2007.

[33] Woldemichael BW, Kimura JI, Dunkley DJ, et al. SHRIMP U-Pb zircon geochronology and $\mathrm{Sr}-\mathrm{Nd}$ isotopic systematic of the Neoproterozoic Ghimbi-Nedjo mafic to intermediate intrusions of western Ethiopia: a record of passive margin magmatism at 855 Ma? Int J Earth Sci 2010; 99: 1773-90.

[34] Grenne T, Pedersen RB, Bjerkgård T, et al. Neoproterozoic evolution of Western Ethiopia: igneous geochemistry, isotope systematics and U-Pb ages. Geol Mag 2003; 140: 373-95.

[35] Teklay M, Berhe K, Reimold WU, et al. Geochemistry and geochronology of a Neoproterozoic low-K tholeiite-Boninite association in central Eritrea. Gondwana Res 2002; 5: 597-611.

[36] Shang CK, Morteani G, Satir M, Taubald H. Neoproterozoic continental growth prior to Gondwana assembly: constrains from zircon-titanite geochronology, geochemistry and petrography of ring complex granitoids, Sudan. Lithos 2010; 118: 61-81.

[37] Shang CK, Satir M, Morteani G, Taubald H. Zircon and titanite age evidence for coeval granitization and migmatization of the early Middle and early Late Proterozoic Saharan Metacraton: example from the central north Sudan basement. J Afr Earth Sci 2010; 57 : 492-524.

[38] Be'eri-Shlevin Y, Katzir Y, Whitehouse M. Post-collisional tectonomagmatic evolution in the northern Arabian-Nubian Shield: time constraints from ion-probe $\mathrm{U}-\mathrm{Pb}$ dating of zircons. J Geol Soc London 2009; 166: 71-85.

[39] Be'eri-Shlevin Y, Samual MD, Azer MK, et al. The Ediacaran Ferani and Rutig volcano-sedimentary succession of the northernmost Arabian-Nubian Shield (ANS): new insights from zircon U-Pb geochronology, geochemistry, and $\mathrm{O}-\mathrm{Nd}$ isotope ratios. Precambrian Res 2011; 188: 21-44.

[40] Stern RJ, Ali KA, Abdelsalam MG, et al. U-Pb zircon geochronology of the eastern part of the Southern Ethiopian shield. Precambrian Res 2012; 206-207: 159-67.

[41] Ali K, Andresen A, Manton WI, et al. U-Pb zircon dating and Sr$\mathrm{Nd}-\mathrm{Hf}$ isotopic evidence to support a juvenile origin of the $\sim 634$ Ma El Shalul granite gneiss dome, Arabian-Nubian Shield. Geol Mag 2012; 149: 783-97.

[42] Ali KA, Azer MK, Gahlan HA, et al. Age constraints on the formation and emplacement of Neoproterozoic ophiolites along the Allaqi-Heiani suture, south Eastern Desert of Egypt. Gondwana Res 2010; 18: 583-95.

[43] Andresen A, Abu El-Rus MA, Myhre PI, et al. U-Pb TIMS age constrains on the evolution of the Neoproterozoic Meatiq gneiss domes, Eastern Desert, Egypt. Int J Earth Sci 2009; 98: 481-497.

[44] Augland LE, Andresen A, Boghdady GY. U-Pb ID-TIMS dating of igneous and metaigneous rocks from the El-Sibai area: time constraints on the tectonic evolution of the Central Eastern Desert, Egypt. Int J Earth Sci 2012; 101: 25-37.

[45] Lundmark AM, Andresen A, Hassan MA, et al. Repeated magmatic pulses in the East African Orogen in the Eastern Desert, Egypt: an old idea supported by new evidence. Gondwana Res 2012; 22: 227-37.

[46] Stern RJ, Kröner A. Late Precambrian crustal evolution in NE Sudan: isotopic and geochronologic constraints. J Geol 1993; 101: 555-574.

[47] Stein M. Tracing the plume material in the Arabian-Nubian Shield. Precambrian Res 2003; 123: 223-34.

[48] Ali BH, Wilde SA, Gabr MMA. Granitoid evolution in Sinai, Egypt, based on precise SHRIMP U-Pb zircon geochronology. Gondwana Res 2009; 15: 38-48.

[49] Ali KA, Wilde SA, Stern RJ, et al. Hf isotopic composition of single zircons from Neoproterozoic arc volcanics and post-collision granites, Eastern Desert of Egypt: implications for crustal growth and recycling in the Arabian-Nubian Shield. Precambrian Res 2013; in press.

[50] Liégeois JP, Stern RJ. Sr-Nd isotopes and geochemistry of granitegneiss complexes from the Meatiq and Hafafit domes, Eastern Desert, Egypt: no evidence for pre-Neoproterozoic crust. J Afr Earth Sci 2010; 57: 31-40.

[51] Teklay M, Kröner A, Mezger K, et al. Geochemistry, Pb-Pb single zircon ages and Nd-Sr isotope composition of Precambrian rocks from southern and eastern Ethiopia: implications for crustal evolution in East Africa. J Afr Earth Sci 1998; 26: 207-27.
[52] Teklay M, Kröner A, Mezger K. Geochemistry, geochronology and isotope geology of Nakfa intrusive rocks, northern Eritrea: products of a tectonically thickened Neoproterozoic arc crust. J Afr Earth Sci 2001; 33: 283-301.

[53] Yibas B, Reimold WU, Armstrong R, et al. The tectonostratigraphy, granitoid geochronology and geological evolution of the Precambrian of southern Ethiopia. J Afr Earth Sci 2002; 34: 57-84.

[54] Kebede T, Koeberl C. Petrogenesis of A-type granitoids from Wallagga area, western Ethiopia: constraints from mineralogy, bulk-rock chemistry, $\mathrm{Nd}$ and $\mathrm{Sr}$ isotopic compositions. Precambrian Res 2003; 121: 1-24.

[55] Beyth M, Stern R, Altherr R, et al. The late Precambrian Timna complex, southern Israel: evidence for comagmatic-type sanukitoid monzodiorite and alkali granite magma. Lithos 1994; 31: 103-24.

[56] Ali KA, Stern RJ, Manton WI, et al. Neoproterozoic diamictite in the Eastern Desert of Egypt and northern Saudi Arabia: evidence of $\sim 750$ Ma glaciation in the Arabian-Nubian Shield? Int J Earth Sci 2010; 99: 705-26.

[57] Ali KA, Stern RJ, Manton WI, et al. Geochemistry, Nd isotopes and U-Pb SHRIMP zircon dating of Neoproterozoic volcanic rocks from the Central Eastern Desert of Egypt: new insights into the $\sim 750$ Ma crust-forming event. Precambrian Res 2009; 171:1-22.

[58] Be'eri-Shlevin Y, Katzir Y, Whitehouse MJ, et al. Contribution of pre-Pan-African crust to formation of the Arabian-Nubian Shield: new SIMS U-Pb and O studies of zircon. Geology 2009; 37: 899902.

[59] Whitehouse MJ, Stoeser DB, Stacey JS. The Khida terranegeochronological and isotopic evidence for Paleoproterozoic and Archean crust in the eastern Arabian Shield of Saudi Arabia. Gondwana Res 2001; 4: 200-2.

[60] Windley FB, Whitehouse MJ, Ba-Bttat MAO. Early Precambrian gneiss terranes and Pan-African island arcs in Yemen: crustal accretion of the eastern Arabian Shield. Geology 1996; 24: 131-4.

[61] Whitehouse MJ, Windley BF, Stoeser DB, et al. Precambrian basement character of Yemen and correlations with Saudi Arabia and Somalia. Precambrian Res 2001; 105: 357-69.

[62] Kröner A, Sassi FP. Evolution of the northern Somalia basement: new constraints from zircon ages. J Afr Earth Sci 1996; 22: 1-15.

[63] Morag N, Avigad D, Gerdes A, et al. 1000-590 Ma crustal evolution in the northern Arabian-Nubian Shield revealed by U-PbHf of detrital zircons from late Neoproterozoic sediments (Elat area, Israel). Precambrian Res 2012; 208-211: 197-212.

[64] Samuel MD, Be'eri-Shlevin Y, Mokhles K, et al. Provenance of conglomerate clasts from the volcano-sedimentary sequences at Wadi Rutig in southern Sinai, Egypt as revealed by SIMS U-Pb dating of zircon. Gondwana Res 2011; 20: 450-64.

[65] Cox GM, Lewis CJ, Collins AS, et al. Ediacaran terrane accretion within the Arabian-Nubian Shield. Gondwana Res 2012; 21: 34152.

[66] Mercolli I, Briner AP, Frie R, et al. Lithostratigraphy and geochronology of the Neoproterozoic crystalline basement of Salalah, Dhofar, Sultanate of Oman. Precambrian Res 2006; 145: 182-206.

[67] Avigad D, Sandler A, Kolodner K, et al. Mass production of Cambrio-Ordovician quartz-rich sandstone as a consequence of chemical weathering of Pan-African terranes; environmental implications. Earth Planet Sci Lett 2005; 240: 818-826.

[68] Kolodner K, Avigad D, McWilliams M, et al. Provenance of north Gondwana Cambrian-Ordovician sandstone: U-Pb SHRIMP dating of detrital zircons from Israel and Jordan. Geol Mag 2006; 143: 367-91.

[69] Konert G, Afifi AM, Al-Hajri SA, et al. Paleozoic stratigraphy and hydrocarbon habitat of the Arabian Platform. GeoArabia 2001; 6: 407-42.

[70] Squire RJ, Campbell IH, Allen CM, et al. Did the Transgondwanan Supermountain trigger the explosive radiation of animals on Earth? Earth Planet Sci Lett 2006; 250: 116-33.

[71] Küster D, Liégeois JP. Sr, Nd isotopes and geochemistry of the Bayuda Desert high-grade metamorphic basement (Sudan): an early Pan-African oceanic convergent margin, not the edge of the East Saharan ghost craton? Precambrian Res 2001; 109: 1-23.

[72] Küster D, Liégeois JP, Matukov D, et al. Zircon geochronology and $\mathrm{Sr}, \mathrm{Nd}, \mathrm{Pb}$ isotope geochemistry of granitoids from Bayuda Desert and Sabaloka (Sudan): evidence for a Bayudian event (920$900 \mathrm{Ma})$ preceding the Pan-African orogenic cycle (860-590 Ma) at 
the eastern boundary of the Saharan Metacraton. Precambrian Res 2008; 164: 16-39.

[73] Be'eri-Shlevin Y, Katzir Y, Blichert-Toft J, et al. Nd-Sr-Hf-O isotope provinciality in the northernmost Arabian-Nubian Shield: implications for crustal evolution. Contrib Mineral Petrol 2010; 160: 181-201.

[74] Johnson PR, Halverson, GP, Kusky M, et al. Volcanosedimentary basins in the Arabian-Nubian Shield: markers of repeated exhumation and denudation in a Neoproterozoic accretionary orogen. Geosciences 2013; 3: 389-445.

[75] Duyverman HJ, Harris NBW, Hawkesworth CJ. Crustal accretion in the Pan-African: $\mathrm{Nd}$ and $\mathrm{Sr}$ isotope evidence from the Arabian Shield. Earth Planet Sci Lett 1982; 59: 315-326.

[76] Zhang RY, Yang JS, Wooden JL, et al. U-Pb SHRIMP geochronology of zircon in garnet peridotite from the Sulu UHP terrane, China: implications for mantle. Earth Planet Sci Lett 2005; 237: 729-43.

[77] Stacey JS, Doe BR, Roberts RJ, et al. Lead isotope study of mineralization in the Saudi Arabian Shield. Contrib Mineral Petrol 1980; 74: 175-188.

[78] Stacey JS, Stoeser DB. Distribution of oceanic and continental leads in the Arabian-Nubian Shield. Contrib Mineral Petrol 1983; 84: 91-105.

[79] Fleck RJ, Greenwood WR, Hadley DG, et al. Rubidium-strontium geochronology and plate-tectonic evolution of the southern part of the Arabian Shield. US Geol Surv Professional Pap 1980; 1131:1105.

[80] Hargrove US, Stern RJ, Kimura JL, et al. How juvenile if the Arabian-Nubian Shield? Evidence from $\mathrm{Nd}$ isotopes and preNeoproterozoic inherited zircon in the Bi'r Umq suture zone, Saudi Arabia. Earth Planet Sci Lett 2006; 252: 308-26.

[81] Sultan M, Tucker RD, El Alfy Z, et al. U-Pb (zircon) ages for the gneissic terrane west of the Nile, southern Egypt. Geol Rundsch 1994; 83: 514-22.

[82] Depaolo DJ, Wasserburg GJ. Nd isotopic variations and petrogenetic models. Geophys Res Lett 1976; 3: 249-52.

[84] Henjes-Kunst F, Altherr R, Baumann A. Evolution and composition of the lithospheric mantle underneath the western Arabian peninsula: constraints from $\mathrm{Sr}-\mathrm{Nd}$ isotope systematics of mantle xenoliths. Miner Petrol 1990; 105: 460-72.

[83] Van Kranendonk MJ, Kirkland CL. Orogenic climax of Earth: the 1.2-1.1 Ga Grenvillian superevent. Geology 2013: 41: 735-8.

[85] McGuire AV, Stern RJ. Granulite xenoliths from western Saudi Arabia: the lower crust of the late Precambrian Arabian-Nubian Shield. Contrib. Mineral Petrol 1993; 114: 395-408.

[86] Blusztajn J, Hart SR, Shimizu N, et al. Trace element and isotopic characteristics of spinel peridotite xenoliths from Saudi Arabia. Chem Geol 1995; 123: 53-65.

[87] Nasir S, Rollinson H. The nature of the subcontinental mantle beneath the Arabian Shield: mantle xenoliths from southern Syria. Precambrian Res 2009; 172: 323-33.

[88] Thornber CR. The petrology, geochemistry and origin of ultramafic inclusions and mafic alkaline volcanics from Harrrat Hutaymah, Saudi Arabia. Ph.D. thesis, Boulder, Colorado, University of Colorado 1992.

[89] Shaw JE, Baker JA, Kent AJR, et al. The geochemistry of the Arabian lithospheric mantle-a source for intraplate volcanism? J Petrol 2007; 48: 1495-1512.

[90] Meiler M, Reshef M, Shulman H. Late Proterozoic - Paleozoic Geology of the Golan Heights and Its Relation to the Surrounding Arabian Platform. In: Dar IA, Dar MA. Earth and Environmental Sciences. InTech 2011; 59-82. Published online: DOI: 10.5772/ 2306.

[91] Zakariadze GS, Dilek Y, Adamia SA, et al. Geochemistry and geochronology of the Neoproterozoic Pan-African Transcaucasian Massif (Republic of Georgia) and implications for island arc evolution of the late Precambrian Arabian-Nubian Shield. Gondwana Res 2007; 11: 92-108.

[92] Ruban DM, Al-Husseni MI, Iwaski Y. Review of Middle East Paleozoic plate tectonics. GeoArabia 2007; 12: 35-56.

[93] Torsvik TH, Cocks LRM. The lower Paleozoic paleogeographical evolution of the northern and eastern peri-Gondwana margin from Turkey to New Zealand. Geol Soc Lond Spec Publ 2009; 325: 321.
[94] Frisch W, Pohl W. Petrochemistry of some mafic and ultramafic rocks from the Mozambique Belt, SE Kenya. Mitteilung Österreichischer Geol Gesells 1986; 78: 97-114.

[95] Hepworth JV. The Mozambique orogenic belt and its foreland in northeast Tanzania: a photographically-based study. J Geol Soc Lond 1972; 128: 461-500.

[96] Fritz H, Tenczer V, Hauzenberger C, et al. Hot granulite nappestectonic styles and thermal evolution of the Proterozoic granulite belts in East Africa. Tectonophysics 2009; 477: 160-173.

[97] Tenczer V, Hauzenberger CA, Fritz H, et al. Anorthosites in the Eastern Granulites of Tanzania-new SIMS zircon U-Pb age data, petrography and geochemistry. Precambrian Res 2006; 148: 85114.

[98] Maboko MAH, Nakamura E. Isotopic dating of Neoproterozoic crustal growth in the Usambara Mountains of northeastern Tanzania: evidence for coeval crustal formation in the Mozambique Ocean and the Arabian-Nubian Shield. Precambrian Res 2002; 113: 227-42.

[99] Bauernhofer AH, Hauzenberger CA, Wallbrecher $\mathrm{R}$, et al. Geochemistry of basement rocks from SW Kenya and NE Tanzania, indications for rifting and early Pan-African subduction. Int J Earth Sci 2009; 98:1809-34.

[100] Abdelsalam G, Dawoud AS. The Kabus ophiolitic mélange, Sudan, and its bearing on the western boundary of the Nubian Shield. J Geol Soc Lond 1991; 148: 83-92.

[101] Abdelsalam MG, Stern RJ, Copeland P, et al. The Neoproterozoic Keraf suture in NE Sudan: sinistral transpression along the eastern margin of West Gondwana. Geology 1998; 106: 133-147.

[102] Harms U, Darbyshire DPF, Denkler T, et al. Evolution of the Neoproterozoic Delgo suture zone and crustal growth in Northern Sudan: geochemical and radiogenic isotope constraints. Geol Rundsch 1994; 83: 591-603.

[104] Bailo T, Schandelmeier H, Franz G, et al. Plutonic and metamorphic rocks from the Keraf suture (NE Sudan): a glimpse of Neoproterozoic tectonic evolution on the NE margin of W. Gondwana. Precambrian Res 2003; 123: 67-80.

[103] Stern RJ, Kröner A, Bender R, et al. Precambrian basement around Wadi Halfa, Sudan: a new perspective on the evolution of the East Saharan Craton. Geol Rundsch 1994; 83: 564-77.

[105] Stern RJ, Abdelsalam MG, Schandelmeier H, et al. Carbonates of the Balateb Group, NE Sudan: a Neoproterozoic (ca $750 \mathrm{Ma}$ ) passive margin on the eastern flank of west Gondwana? Geol Soc Am Abs Prog 1993; 27: 49.

[106] Schandelmeier H, Wipfler E, Küster D, et al. Atmur-Delgo suture: a Neoproterozoic oceanic basin extending into the interior of northeast Africa. Geology 1994; 22: 563-566.

[107] Johnson PR, Abdelsalam MG, Stern RJ. The Bi'r Umq-Nakasib suture zone in the Arabian-Nubian Shield: a key to understanding crustal growth in the East African Orogen. Gondwana Res 2003; 6 : 523-30.

[108] Gindy AR, Tamish MM. Petrogenetic revision of the basement rocks in the environs of Aswan, southern Egypt. Egypt J Geol 1998; 42: 1-14.

[109] Finger F, Dörr W, Gerdes A, et al. U-Pb zircon ages and geochemical data for the Monumental Granite and other granitoid rocks from Aswan, Egypt: implications for the geological evolution of the western margin of the Arabian-Nubian Shield. Miner Petrol 2008; 93: 153-83.

[110] Stern RJ, Hedge CE. Geochronology and isotopic constraints on late Precambrian crustal evolution in the Eastern Desert of Egypt. Am J Sci 1985; 285: 97-127.

[111] Harms U, Schandelmeier H, Darbyshire DPF. Pan-African reworked early/middle Proterozoic crust in NE Africa west of the Nile: $\mathrm{Sr}$ and Nd isotopes evidence. J Geol Soc Lond 1990; 147 859-72.

[112] Doebrich JL, Al-Jehani AM, Siddiqui AA, et al. Geology and metallogeny of the Ar Rayn terrane, eastern Arabian Shield: evolution of a Neoproterozoic continental-margin arc during assembly of Gondwana within the East African Orogen. Precambrian Res 2007; 158: 17-50.

[113] Be'eri-Shlevin Y, Eyal M, Eyal Y, et al. The Sa'al volcanosedimentary complex (Sinai, Egypt): a latest Mesoproterozoic volcanic arc in the northern Arabian-Nubian Shield. Geology 2012; 40: 403-6.

[114] Bea R, Abu-Anbar M, Montero P. et al. The 844 Ma Moneiga quartz-diorites of the Sinai, Egypt: evidence for Andean-type arc or 
rift-related magmatism in the Arabian-Nubian Shield? Precambrian Res 2009; 175: 161-8.

[115] Denèle Y, Leroy S, Pelleters E, et al. The Cryogenian arc formation and successive high-K calc-alkaline plutons of Socotra Island (Yemen). Arab J Geosci 2012; 5: 903-924.

[116] Whitehouse MJ, Windley BF, Ba-Bttat MAO, et al. Crustal evolution and terrane correlation in the eastern Arabian Shield, Yemen: geochronological constraints. J Geol Soc Lond 1998; 155:281-296.

[117] Stoeser DB, Stacey JS. Evolution, U-Pb geochronology, and isotope geology of the Pan African Nabitah orogenic belt of the Saudi Arabian Shield. In: El-Gaby S, Greiling RO, Eds. The PanAfrican Bbelt of Northeast Africa and adjacent areas. Braunschweig/Wiesbaden, Vieweg und Sohn 1988; pp. 227-288.

[118] Stoeser DB, Whitehouse MJ, Stacey JS. The Khida terrane geology of Paleoproterozoic rocks in the Muhayil area, eastern Arabian Shield, Saudi Arabia. Gondwana Res 2001; 4: 192-4.

[119] Stacey JS, Hedge CE. Geochronologic and isotopic evidence for early Proterozoic crust in the eastern Arabian Shield. Geology 1984; 12: 310-3.

[120] Stacey JS, Agar A. U-Pb isotopic evidence for the accretion of a continental microplate in the Zalm region of the Saudi Arabian Shield. J Geol Soc Lond 1985; 142: 1189-203.

[121] Getings ME, Blank HR, Mooney WD. Crustal structure of southwestern Saudi Arabia. J Geophys Res 1986; 91: 6491-512.

[122] Al-Husseini MI. Origin of Arabian Plate structures; Amar collision and Najd rift. GeoArabia 2000; 5: 527-42.

[123] Coleman RG. Reconnaissance geology of the Khamis Mushayt quadrangle, Kingdom of Saudi Arabia. Jiddah, Saudi Arabia, Directorate General of Mineral Resources 1973.

[124] Stern RJ, Johnson PR, Kröner A, et al. In: Kusky TM, Ed. Precambrian ophiolites and related rocks: Developments in Precambrian geology. Amsterdam, Elsevier 2004; vol. 13: pp. 95128.

[125] Stoeser DB, Fleck RJ, Stacey, JS. Geochronology and origin of an early tonalite gneiss of the Wadi Tarib batholith and the formation of syn-tectonic gneiss complexes in the southwestern Arabian Shield, Kingdom of Saudi Arabia. Jiddah, Saudi Arabia, Deputy Ministry for Mineral Resources 1982.

[126] Engel AEJ, Cixon TH, Stern RJ. Late Precambrian evolution of Afro-Arabian crust from ocean arc to craton. Geol Soc Am Bull 1980; 91: 699-706.

[127] Pilot J, Werner CD, Haubrich F, et al. Paleozoic and Proterozoic zircons from the mid-Atlantic Ridge. Nature 1998; 393: 676-679.
[128] Belyatsky B, Lepekhina E, Antonov A, et al. Geochemical signatures of oceanic crust zircon. Geochim Cosmochim 2008; 72: A71.

[129] Whattam SA, Malpas J, Smith IEM, et al. Link between SSZ ophiolite formation, emplacement and arc inception, Northland, New Zealand: U-Pb SHRIMP constraints; Cenozoic SW Pacific tectonic implications. Earth Planet Sci Lett 2006; 250: 606-32.

[130] Pallister JS, Stacey JS, Fischer LB, et al. Precambrian ophiolites of Arabia: geologic settings, U-Pb geochronology, $\mathrm{Pb}$-isotope characteristics, and implications for continental accretion. Precambrian Res 1988; 38: 1-54.

[131] Hargrove US, Stern RJ, Griffin WR, et al. From island arc to craton: timescales of crustal formation along the Neoproterozoic Bi'r Umq suture zone, Kingdom of Saudi Arabia. Jiddah, Saudi Geological Survey 2006.

[132] Hamilton W. Tectonics of the Indonesian region. US Geol Surv Professional Pap 1979; 1078: 1-345.

[133] Condie KC. In Yoshida M, Windley BF, Dasgupta S, Eds. Proterozoic East Gondwana: Supercontinent Assembly and Breakup. Lond Geol Soc 2003; 1-21.

[134] Goodwin AM. Principles of Precambrian geology. San Diego, Academic Press; 1996.

[135] Reymer A, Schubert G. Phanerozoic addition rates to the continental crust and crustal growth rates. Tectonics 1984; 3: 6377.

[136] Dixon TH, Golombek MP. Late Precambrian crustal accretion rates in northeast Africa and Arabia. Geology 1988; 16: 991-994.

[137] Stern RJ, Abdelsalam MG. Formation of juvenile continental crust in the Arabian-Nubian Shield: evidence from granitic rocks of the Nakasib suture. NE Sudan Geol Rundsch 1998; 87: 150-160.

[138] Schandelmeier H, Abdel Rahman EM, Wipfler E, et al. Late Proterozoic magmatism in the Nakasib sutures, Red Sea Hills, Sudan. J Geol Soc Lond 1994; 151: 485-97.

[139] Moussa EMM, Stern RJ, Manton WI, et al. SHRIMP zircon dating and $\mathrm{Sm} / \mathrm{Nd}$ isotopic investigations of Neoproterozoic granitoids, Eastern Desert, Egypt. Precambrian Res 2008; 160: 341-56.

[140] Kröner A, Todt W, Husseini IM, et al. Dating of late Proterozoic ophiolites in Egypt and the Sudan using the single grain zircon evaporation technique. Precambrian Res 1992; 59: 15-32.

[141] Zimmer M, Kröner A, Jochum KP, et al. The Gabal Gerf complex: a Precambrian N-MORB ophiolite in the Nubian Shield, NE Africa. Chem Geol 1995; 123: 29-51. 